\title{
Changes in soil carbon stocks in Brazil due to land use: paired site comparisons and a regional pasture soil survey
}

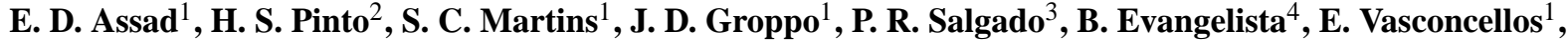 \\ E. E. Sano ${ }^{4}$, E. Pavão ${ }^{1}$, R. Luna ${ }^{1}$, P. B. Camargo ${ }^{5}$, and L. A. Martinelli ${ }^{5}$ \\ ${ }^{1}$ Brazilian Agricultural Research Corporation, EMBRAPA Agricultural Informatics, Campinas, São Paulo State, Brazil \\ ${ }^{2}$ University of Campinas - UNICAMP, Campinas, São Paulo State, Brazil \\ ${ }^{3}$ Brazilian Agricultural Research Corporation, EMBRAPA Coffe, Brasilia, DF, Brazil \\ ${ }^{4}$ Brazilian Agricultural Research Corporation, EMBRAPA Agropecuária do Cerrado, Brasilia, DF, Brazil \\ ${ }^{5}$ University of São Paulo - USP, Centro de Energia Nuclear na Agricultura, Piracicaba, São Paulo State, Brazil
}

Correspondence to: E. D. Assad (edu.assad@gmail.com)

Received: 20 December 2012 - Published in Biogeosciences Discuss.: 21 March 2013

Revised: 29 July 2013 - Accepted: 23 August 2013 - Published: 1 October 2013

\begin{abstract}
In this paper we calculated soil carbon stocks in Brazil studying 17 paired sites where soil stocks were determined in native vegetation, pastures and crop-livestock systems (CPS), and in other regional samplings encompassing more than 100 pasture soils, from 6.58 to $31.53^{\circ} \mathrm{S}$, involving three major Brazilian biomes: Cerrado, Atlantic Forest, and the Pampa. The average native vegetation soil carbon stocks at 10,30 and $60 \mathrm{~cm}$ soil depth were equal to approximately 29,64 , and $92 \mathrm{Mgha}^{-1}$, respectively. In the paired sites, carbon losses of $7.5 \mathrm{Mg} \mathrm{ha}^{-1}$ and $11.6 \mathrm{Mg} \mathrm{ha}^{-1}$ in CPS systems were observed at $10 \mathrm{~cm}$ and $30 \mathrm{~cm}$ soil depths, respectively. In pasture soils, carbon losses were similar and equal to $7.5 \mathrm{Mg} \mathrm{ha}^{-1}$ and $11.0 \mathrm{Mg} \mathrm{ha}^{-1}$ at $10 \mathrm{~cm}$ and $30 \mathrm{~cm}$ soil depths, respectively. Differences at $60 \mathrm{~cm}$ soil depth were not significantly different between land uses. The average soil $\delta^{13} \mathrm{C}$ under native vegetation at 10 and $30 \mathrm{~cm}$ depth were equal to $-25.4 \%$ and $-24.0 \%$ o, increasing to $-19.6 \%$ and $-17.7 \%$ in CPS, and to $-18.9 \%$, and $-18.3 \%$ in pasture soils, respectively; indicating an increasing contribution of $\mathrm{C}_{4}$ carbon in these agrosystems. In the regional survey of pasture soils, the soil carbon stock at $30 \mathrm{~cm}$ was equal to approximately $51 \mathrm{Mg} \mathrm{ha}^{-1}$, with an average $\delta^{13} \mathrm{C}$ value of $-19.6 \%$. Key controllers of soil carbon stock in pasture sites were sand content and mean annual temperature. Collectively, both could explain approximately half of the variance of soil carbon stocks. When pasture soil carbon stocks were compared with the average soil carbon stocks of native vegetation estimated for Brazilian biomes and soil types by
\end{abstract}

Bernoux et al. (2002) there was a carbon gain of $6.7 \mathrm{Mg} \mathrm{ha}^{-1}$, which is equivalent to a carbon gain of $15 \%$ compared to the carbon soil stock of the native vegetation. The findings of this study are consistent with differences found between regional comparisons like our pasture sites and plot-level paired study sites in estimating soil carbon stocks changes due to land use changes.

\section{Introduction}

Soil has long been recognized as the largest organic carbon reservoir of terrestrial systems of the Earth (Post et al., 1982). It has been estimated that globally approximately $1500 \mathrm{Pg}$ of carbon is stored in the first meter of topsoil. Tropical soils store approximately $40 \%$ of this total, with tropical evergreen forests being the single largest reservoir of soil carbon (Jobbágy and Jackson, 2000). Soil carbon exchange with the atmosphere through soil respiration is also an important component of the global carbon cycle and it was estimated to be approximately $80 \mathrm{Pg} \mathrm{Cyr}^{-1}$ (Raich and Potter, 1995).

It is now also well established that carbon pools in the soil have distinct residence times. The more recalcitrant material composing the majority of soil carbon is a low cycling carbon that it is not affected much by recent land use changes (Trumbore et al., 1995; Zinn et al., 2005; Lisboa et al., 2009; Eclesia et al., 2012; Chen et al., 2013). On the other hand, there is a much faster cycling pool, that although in lower amounts 
than the recalcitrant material, plays a key role because of its quick response to recent land use changes (Trumbore et al., 1995; Zinn et al., 2005; Lisboa et al., 2009; Eclesia et al., 2012; Chen et al., 2013). As a consequence, it is possible for humans to manage soils in order to accumulate carbon or avoid high losses of it with cultivation (Lal, 2010). For instance, in the early nineties, Fisher et al. (1994) estimated that the introduction of deep-rooted grasses in South America could sequester between approximately 100 to 500 million metric ton of carbon per year.

In this regard, it is reasonable to conclude after several regional and global studies that, in general, the conversion of natural vegetation to arable lands tends to decrease the soil carbon stocks at least in the more surface soil depths (Davidson and Ackerman, 1993; Amundson, 2001; Guo and Gifford, 2002; Ogle et al., 2005; Baker et al., 2007; Don et al., 2011; Eclisa et al. 2012). However, it has also been shown that in several plot-scale studies, depending on the type of land use change, climate, and agricultural practices, soil carbon stocks may increase or become neutral compared to the soil stocks under original vegetation (Guo and Gifford, 2002; Ogle et al., 2005; Zinn et al., 2005; Braz et al., 2013). Especially relevant for this study was the regional survey made in South America that showed a gain of carbon in surface soils where primary vegetation were replaced by pastures, and the fact that in the case of replacing native vegetation by croplands, there was a gain of carbon under low rainfall and a loss under high rainfall areas (Eclisa et al., 2012).

It is also relevant that the adoption of agriculture practices, such as no till and crop-livestock systems, generally leads to an increase in soil carbon stocks at least at more surface depths (Sá et al., 2001; Ogle et al., 2005; Zinn et al. 2005; Bayer et al., 2006, 2007).

One of the most intense land use changes has taken place in Brazil over recent decades (Leite et al., 2012). This land use change has increased the agricultural area of Brazil to approximately 270 million hectares, being 200 million hectares of pasture and 70 million hectares of arable land (Martinelli et al., 2010). As a consequence, land use changes in Brazil are responsible for $25 \%$ of the carbon emissions linked to global land use changes, and also responsible for almost $80 \%$ of the total carbon emissions in Brazil in 2005 (MCT, 2010). On the other hand, no-till is already present in more than 27 million hectares in Brazil and crop-livestock systems have been more readily adopted, mainly in the southern region of the country (Boddey et al., 2010).

Additionally, a particular program was proposed by the Brazilian government that encourages the adoption of good agricultural practices to promote low carbon emission agriculture (Low Carbon Emission Program - ABC Program). This program, which is prescribed by law (Law no. 12187 of 29 December 2009), establishes that mitigation should be conducted by the adoption of: (i) recovery of degraded pastures, (ii) a no-tillage system, (iii) integrated livestock-cropforest systems, and (iv) re-forestation in order to reduce ap- proximately 35 to $40 \%$ of projected greenhouse gas emissions by 2020 . Therefore, greater knowledge of soil carbon stocks is fundamental for the country, because these stocks are a very important component in low carbon emission agriculture. In this regard, although there have been several plotscale studies (e.g. Sá et al., 2001; Bayer et al., 2006; Marchão et al., 2009; Maia et al., 2009; Braz et al., 2012), due to the vast area of Brazil, there has not been sufficient studies to establish a countrywide perspective (Smith et al., 2012).

Based on the above discussion, the main objective of this paper is to evaluate the effects of land use changes on carbon soil stocks in several Brazilian regions. In order to achieve this objective, two approaches were pursued. One was conducted at plot scale in 17 paired sites comparing soil stocks among native vegetation, pastures and crop-livestock systems; the other was a regional survey of pasture soils where more than 100 sites were sampled and compared with the averages of native vegetation soil stocks obtained in the literature. The stable carbon isotopic composition of soil organic matter $\left(\delta^{13} \mathrm{C}\right)$ was also determined in sites to evaluate the origin of the carbon incorporated in the soil organic matter (Lisboa et al., 2009). This technique is especially useful in Brazil where land conversion in most cases involves the replacement of a $\mathrm{C}_{3}$ vegetation (native forest) by a $\mathrm{C}_{4}$ pasture or crops like maize (Bernoux et al., 1998).

This is the first time that such a large number of sites have been analyzed in a single study. These sites encompass a broad range of climatic conditions and soil composition allowing us to establish main control factors of carbon soil stocks, and allowing for a consistent analysis of the effects of land use changes on soil carbon stocks. Finally, the data set presented in this study may contribute to modeling efforts to evaluate changes in soil carbon stocks due to land use changes, which is considered one of the most efficient and affordable ways to estimate such changes (Smith et al., 2012).

\section{Material and methods}

\subsection{Study area}

The regional pasture survey, conducted in November and December of 2010, encompassing soils from more than 100 pastures located between 6.58 and $31.53^{\circ} \mathrm{S}$ were selected based first on satellite images in an attempt to broadly encompass three major Brazilian biomes: Cerrado, Atlantic Forest and Pampa (Fig. 1); and, secondly, sites were also selected based on their access by roads (Fig. 1). We are aware that this may introduce a bias in our sampling scheme, but it would be impossible due to time and economic constraints to sample remote areas with limited access. Additionally, although all pastures were in use at the time of the study, it was difficult to visually judge their grazing conditions or their stocking rates. We are also aware that such information would be extremely 


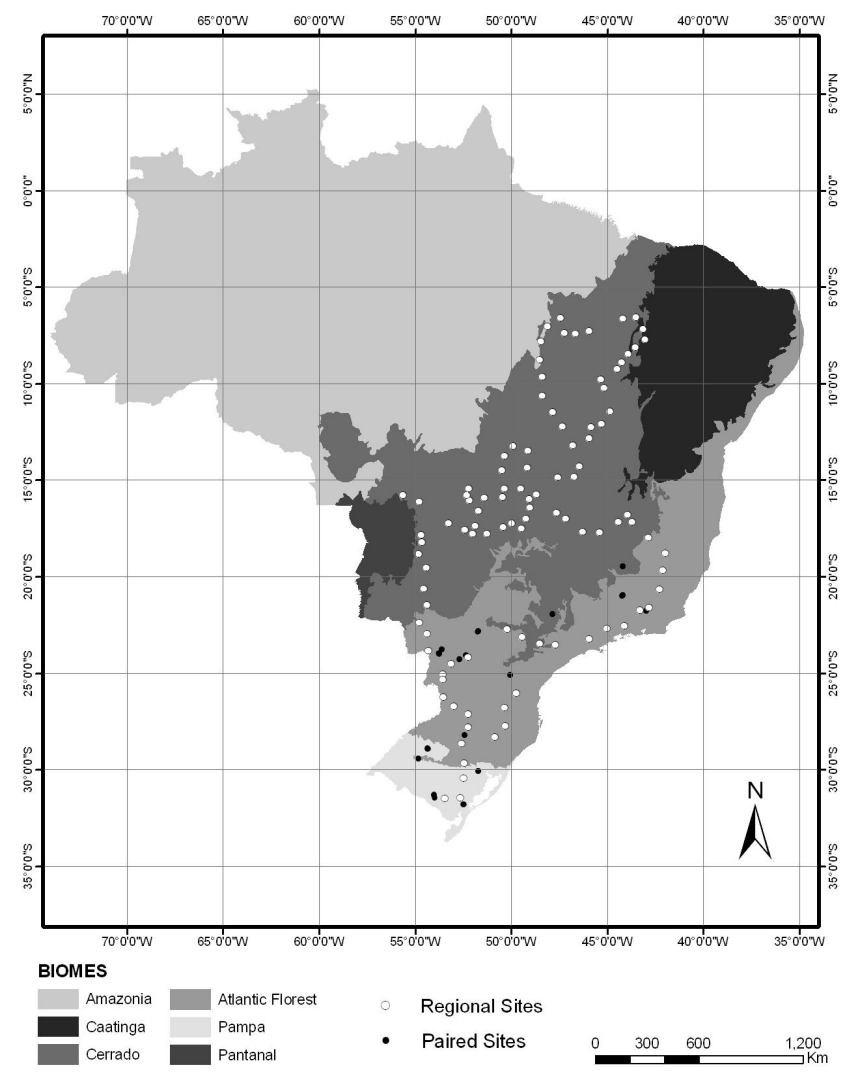

Fig. 1. Sampling sites distributed throughout Brazil. Open circles indicate pasture sites of the regional survey; closed circles indicate paired study sites, and gray shadows, Brazilian biomes.

useful because it is well established that carbon soil stocks vary with pasture conditions (Camargo et al., 1999; Maia et al., 2009). For instance, Braz et al. (2013) found a significant difference between degraded and non-degraded pastures in the Brazilian Cerrado. At the same time, these authors pointed out the difficulties in determining grazing conditions in Brazilian pastures, where the land use history is poorly known and farmers do not keep records of vital information such as the use of fertilizers and stocking rates.

Soil samples of the 17 paired study sites selected by the Embrapa regional offices were sampled between November and December 2011. In these sites, we tried to sample areas of pasture, crop-livestock systems (CPS) and native vegetation, but it was not always possible to find these three land uses in the same site (Table 1). With the exception of pasture soil or CPS sites located in the southern region of the country cultivated with a $\mathrm{C}_{3}$ grass (Lolium perenne), all other pastures or CPS sites were cultivated with a $\mathrm{C}_{4}$ grass species, especially grasses of the genus Brachiaria.

As much as possible, the history of the land use changes was investigated by talking with local farmers. However, such information is always difficult to obtain with accuracy in Brazil. Therefore, we cannot say with certainty, for in- stance, that the native vegetation was undisturbed primary vegetation. In this regard we used the $\delta^{13} \mathrm{C}$ values of soil organic matter to investigate the presence of $\mathrm{C}_{4}$ carbon as indirect evidence of past native vegetation disturbance.

\subsection{Precipitation and temperature}

The precipitation and temperatures were obtained using the Prediction of Worldwide Energy Resource (POWER) Project (http://power.larc.nasa.gov).

\subsection{Sample collection and analysis}

In each site, a trench of $60 \mathrm{~cm}$ by $60 \mathrm{~cm}$, yielding an area of approximately $360 \mathrm{~cm}^{2}$ was excavated. For the pasture regional survey, the depth of the trench was approximately $30 \mathrm{~cm}$, and in the paired sites, the depth was approximately $60 \mathrm{~cm}$. Trenches were excavated according to interval depths, samples for bulk density were collected first and after approximately $500 \mathrm{~g}$ of soil were collected for chemical analysis.

Air-dried soil samples were separated from plant material and stones, and then homogenized. The samples were then run through a sieve for chemical and physical analysis $(2.0 \mathrm{~mm})$ and analysis of soil carbon $(0.15 \mathrm{~mm})$.

The particle size was assessed after chemical dispersion to determine the amount of sand, silt and clay soil, using the hydrometer method (Embrapa, 1997). The concentration of soil carbon and stable carbon isotopic composition was determined by using the elemental analyzer and mass spectrometry at the Laboratory of Isotopic Ecology Center for Nuclear Energy in Agriculture, University of São Paulo (CENA-USP) in Piracicaba, Brazil. Isotopic analyses were performed in a Thermo Finnigan Delta Plus spectrometer. Ratios were expressed by the classical $\delta$ per mil notation:

$\delta=\left(R_{\text {sample }}-R_{\text {standard }}-1\right) \times 1000$,

where $R_{\text {sample }}$ and $R_{\text {standard }}$ are the ${ }^{13} \mathrm{C}:{ }^{12} \mathrm{C}$ ratio of samples and standard, respectively. The standard use for carbon was Vienna Peedee Belemnite (VPDB). The analytical precision values were obtained based on duplicate measurements of internal, calibrated standards routinely used in the laboratory and samples from the present study. The analytical error for $\delta^{13} \mathrm{C}$ was $0.2 \%$.

\subsection{Soil carbon stocks}

Carbon stocks expressed in $\mathrm{Mg} \mathrm{ha}^{-1}$ were calculated for the soil depth intervals $0-10 \mathrm{~cm}, 0-30 \mathrm{~cm}$, and $0-60 \mathrm{~cm}$ for the paired sites and $0-10 \mathrm{~cm}$, and $0-30 \mathrm{~cm}$ for the pasture regional survey by sum stocks obtained in each sampling intervals $(0-5,5-10,10-20,20-30,30-40,40-60 \mathrm{~cm})$.

Soil carbon stocks were estimated based on a fixed mass in order to correct for differences caused by land use changes in soil density (Wendt and Hauser, 2013) using 
Table 1. Characterization of sampled sites: native vegetation (NV), pastures (P), crop-livestock systems (CL), livestock-forest systems (LF), crop-forest systems (CF) and crop-livestock-forest systems (CLF).

\begin{tabular}{|c|c|c|c|c|c|c|}
\hline $\begin{array}{l}\text { City }(\text { Code })- \\
\text { State }\end{array}$ & Point & Latitude & Longitude & Land use system & Established & Biome \\
\hline \multirow{5}{*}{$\begin{array}{l}\text { Sete Lagoas } \\
(\mathrm{SL})-\mathrm{MG}\end{array}$} & 1 & $19^{\circ} 29^{\prime} 57^{\prime \prime}$ & $44^{\circ} 11^{\prime} 03^{\prime \prime}$ & Pasture & - & Cerrado \\
\hline & 2 & $19^{\circ} 29^{\prime} 24^{\prime \prime}$ & $44^{\circ} 10^{\prime} 48^{\prime \prime}$ & $\begin{array}{l}\text { CL ( } 1 \mathrm{yr} \text { of pasture } \\
\text { followed by } 2 \mathrm{yr} \text { of } \\
\text { corn) }\end{array}$ & - & Cerrado \\
\hline & 3 & $19^{\circ} 29^{\prime} 11^{\prime \prime}$ & $44^{\circ} 11^{\prime} 19^{\prime \prime}$ & $\begin{array}{l}\text { CLF (corn, pasture and } \\
\text { eucalyptus) }\end{array}$ & 2009 & Cerrado \\
\hline & 4 & $19^{\circ} 29^{\prime} 37^{\prime \prime}$ & $44^{\circ} 11^{\prime} 09^{\prime \prime}$ & Native Vegetation & - & Cerrado \\
\hline & 5 & $19^{\circ} 29^{\prime} 28^{\prime \prime}$ & $44^{\circ} 11^{\prime} 08^{\prime \prime}$ & $\begin{array}{l}\text { CL ( } 1 \mathrm{yr} \text { of pasture } \\
\text { followed by } 2 \mathrm{yr} \text { of } \\
\text { soybean) }\end{array}$ & - & Cerrado \\
\hline \multirow{6}{*}{$\begin{array}{l}\text { Coronel Xavier } \\
(\mathrm{CX})-\mathrm{MG}\end{array}$} & 6 & $21^{\circ} 01^{\prime} 06^{\prime \prime}$ & $44^{\circ} 12^{\prime} 53^{\prime \prime}$ & Native Vegetation & - & Atlantic Forest \\
\hline & 7 & $21^{\circ} 01^{\prime} 13^{\prime \prime}$ & $44^{\circ} 12^{\prime} 56^{\prime \prime}$ & Pasture & - & Atlantic Forest \\
\hline & 8 & $21^{\circ} 01^{\prime} 12^{\prime \prime}$ & $44^{\circ} 12^{\prime} 53^{\prime \prime}$ & $\begin{array}{l}\text { CLF (corn, pasture and } \\
\text { eucalyptus) }\end{array}$ & 2009 & Atlantic Forest \\
\hline & 9 & $20^{\circ} 59^{\prime} 35^{\prime \prime}$ & $44^{\circ} 10^{\prime} 18^{\prime \prime}$ & Pasture & - & Atlantic Forest \\
\hline & 10 & $20^{\circ} 59^{\prime} 36^{\prime \prime}$ & $44^{\circ} 10^{\prime} 18^{\prime \prime}$ & Native Vegetation & - & Atlantic Forest \\
\hline & 11 & $20^{\circ} 59^{\prime} 40^{\prime \prime}$ & $44^{\circ} 10^{\prime} 20^{\prime \prime}$ & $\begin{array}{l}\text { CLF (corn, pasture and } \\
\text { eucalyptus) }\end{array}$ & 2009 & Atlantic Forest \\
\hline \multirow{4}{*}{$\begin{array}{l}\text { São Carlos } \\
(\mathrm{SC})-\mathrm{SP}\end{array}$} & 15 & $21^{\circ} 58^{\prime} 49^{\prime \prime}$ & $47^{\circ} 51^{\prime} 10^{\prime \prime}$ & Pasture & - & Cerrado \\
\hline & 16 & $21^{\circ} 58^{\prime} 27^{\prime \prime}$ & $47^{\circ} 51^{\prime} 10^{\prime \prime}$ & $\begin{array}{l}\text { LF (pasture and } \\
\text { eucalyptus) }\end{array}$ & 2010 & Cerrado \\
\hline & 17 & $21^{\circ} 58^{\prime} 38^{\prime \prime}$ & $47^{\circ} 51^{\prime} 17^{\prime \prime}$ & Native Vegetation & - & Cerrado \\
\hline & 18 & $21^{\circ} 57^{\prime} 47^{\prime \prime}$ & $47^{\circ} 51^{\prime} 00^{\prime \prime}$ & $\begin{array}{l}\text { LF (pasture and } \\
\text { eucalyptus) }\end{array}$ & 2007 & Cerrado \\
\hline \multirow[t]{3}{*}{$\begin{array}{l}\text { Cafeara }(\mathrm{CS})- \\
\text { PR }\end{array}$} & 19 & $22^{\circ} 50^{\prime} 38^{\prime \prime}$ & $51^{\circ} 42^{\prime} 28^{\prime \prime}$ & $\begin{array}{l}\text { CL (pasture and } \\
\text { soybean) }\end{array}$ & 2003 & Atlantic Forest \\
\hline & 20 & $22^{\circ} 50^{\prime} 02^{\prime \prime}$ & $51^{\circ} 42^{\prime} 52^{\prime \prime}$ & Native Vegetation & - & Atlantic Forest \\
\hline & 21 & $22^{\circ} 52^{\prime} 12^{\prime \prime}$ & $51^{\circ} 43^{\prime} 37^{\prime \prime}$ & Pasture & - & Atlantic Forest \\
\hline \multirow[t]{3}{*}{ Iporã (IP) - PR } & 22 & $24^{\circ} 00^{\prime} 26^{\prime \prime}$ & $53^{\circ} 45^{\prime} 01^{\prime \prime}$ & $\begin{array}{l}\text { CL (1 yr of pasture } \\
\text { and } 3 \text { yr of soybean) }\end{array}$ & - & Atlantic Forest \\
\hline & 23 & $24^{\circ} 00^{\prime} 06^{\prime \prime}$ & $53^{\circ} 45^{\prime} 32^{\prime \prime}$ & Pasture & - & Atlantic Forest \\
\hline & 24 & $24^{\circ} 01^{\prime} 20^{\prime \prime}$ & $53^{\circ} 45^{\prime} 38^{\prime \prime}$ & Native Vegetation & - & Atlantic Forest \\
\hline \multirow{4}{*}{$\begin{array}{l}\text { Xambrê (XA) - } \\
\text { PR }\end{array}$} & 25 & $23^{\circ} 47^{\prime} 34^{\prime \prime}$ & $53^{\circ} 36^{\prime} 20^{\prime \prime}$ & Pasture & - & Atlantic Forest \\
\hline & 26 & $23^{\circ} 47^{\prime} 14^{\prime \prime}$ & $53^{\circ} 36^{\prime} 10^{\prime \prime}$ & $\begin{array}{l}\text { CL (pasture and } \\
\text { soybean) }\end{array}$ & 2000 & Atlantic Forest \\
\hline & 27 & $23^{\circ} 47^{\prime} 23^{\prime \prime}$ & $53^{\circ} 36^{\prime} 31^{\prime \prime}$ & $\begin{array}{l}\mathrm{CF} \text { (soybean and } \\
\text { eucalyptus) }\end{array}$ & 2010 & Atlantic Forest \\
\hline & 28 & $23^{\circ} 48^{\prime} 29^{\prime \prime}$ & $53^{\circ} 35^{\prime} 25^{\prime \prime}$ & Native Vegetation & - & Atlantic Forest \\
\hline \multirow{3}{*}{$\begin{array}{l}\text { Campo Mourão } \\
(\mathrm{CM})-\mathrm{PR}\end{array}$} & 29 & $24^{\circ} 06^{\prime} 25^{\prime \prime}$ & $52^{\circ} 21^{\prime} 40^{\prime \prime}$ & Pasture & - & Atlantic Forest \\
\hline & 30 & $24^{\circ} 06^{\prime} 21^{\prime \prime}$ & $52^{\circ} 21^{\prime} 34^{\prime \prime}$ & CL (corn and pasture) & 2001 & Atlantic Forest \\
\hline & 31 & $24^{\circ} 06^{\prime} 18^{\prime \prime}$ & $52^{\circ} 21^{\prime} 34^{\prime \prime}$ & Native Vegetation & - & Atlantic Forest \\
\hline
\end{tabular}


Table 1. Continued.

\begin{tabular}{|c|c|c|c|c|c|c|}
\hline $\begin{array}{l}\text { City }(\text { Code })- \\
\text { State }\end{array}$ & Point & Latitude & Longitude & Land use system & Established & Biome \\
\hline \multirow[t]{3}{*}{$\begin{array}{l}\text { Juranda }(\mathrm{JU})- \\
\text { PR }\end{array}$} & 32 & $24^{\circ} 18^{\prime} 21^{\prime \prime}$ & $52^{\circ} 42^{\prime} 17^{\prime \prime}$ & $\begin{array}{l}\text { CL (rotation soybean or } \\
\text { corn and pasture) }\end{array}$ & 2006 & Atlantic Forest \\
\hline & 33 & $24^{\circ} 18^{\prime} 34^{\prime \prime}$ & $52^{\circ} 42^{\prime} 16^{\prime \prime}$ & Pasture & - & Atlantic Forest \\
\hline & 34 & $24^{\circ} 18^{\prime} 10^{\prime \prime}$ & $52^{\circ} 42^{\prime} 18^{\prime \prime}$ & Native Vegetation & - & Atlantic Forest \\
\hline \multirow[t]{4}{*}{$\begin{array}{l}\text { Ponta Grossa } \\
\text { (PG)- PR }\end{array}$} & 35 & $25^{\circ} 06^{\prime} 37^{\prime \prime}$ & $50^{\circ} 03^{\prime} 04^{\prime \prime}$ & $\begin{array}{l}\text { CLF (soybean, pasture } \\
\text { and eucalyptus) }\end{array}$ & 2006 & Atlantic Forest \\
\hline & 36 & $25^{\circ} 06^{\prime} 32^{\prime \prime}$ & $50^{\circ} 03^{\prime} 26^{\prime \prime}$ & $\begin{array}{l}\text { CL (soy in summer and } \\
\text { oats in winter) }\end{array}$ & 10 & Atlantic Forest \\
\hline & 37 & $25^{\circ} 06^{\prime} 43^{\prime \prime}$ & $50^{\circ} 03^{\prime} 49^{\prime \prime}$ & Native Vegetation & - & Atlantic Forest \\
\hline & 38 & $25^{\circ} 06^{\prime} 54^{\prime \prime}$ & $50^{\circ} 03^{\prime} 49^{\prime \prime}$ & Pasture & - & Atlantic Forest \\
\hline \multirow[t]{4}{*}{$\begin{array}{l}\text { Arroio dos Ratos } \\
(\mathrm{AR})-\mathrm{RS}\end{array}$} & 39 & $30^{\circ} 06^{\prime} 14^{\prime \prime}$ & $51^{\circ} 41^{\prime} 32^{\prime \prime}$ & $\begin{array}{l}\text { CL (soy in summer } \\
\text { and } L . \text { multiflorum } \\
\text { in winter) }\end{array}$ & 2002 & Pampa \\
\hline & 40 & $30^{\circ} 06^{\prime} 12^{\prime \prime}$ & $51^{\circ} 41^{\prime} 33^{\prime \prime}$ & $\begin{array}{l}\text { CL (corn or soy } \\
\text { in summer and } \\
\text { L. multiflorum } \\
\text { in the winter) }\end{array}$ & 2002 & Pampa \\
\hline & 41 & $30^{\circ} 06^{\prime} 06^{\prime \prime}$ & $51^{\circ} 41^{\prime} 58^{\prime \prime}$ & Native Vegetation & - & Pampa \\
\hline & 42 & $30^{\circ} 06^{\prime} 06^{\prime \prime}$ & $51^{\circ} 41^{\prime} 31^{\prime \prime}$ & Pasture & - & Pampa \\
\hline \multirow[t]{4}{*}{$\begin{array}{l}\text { Tuparecetã } \\
(\mathrm{TU})-\mathrm{RS}\end{array}$} & 43 & $28^{\circ} 56^{\prime} 34^{\prime \prime}$ & $54^{\circ} 21^{\prime} 35^{\prime \prime}$ & $\begin{array}{l}\text { CL (soy in summer and } \\
\text { L. multiflorum in win- } \\
\text { ter) }\end{array}$ & 2001 & Pampa \\
\hline & 44 & $28^{\circ} 56^{\prime} 11^{\prime \prime}$ & $54^{\circ} 21^{\prime} 25^{\prime \prime}$ & $\begin{array}{l}\text { CL (soy in summer and } \\
\text { L. multiflorum in win- } \\
\text { ter) }\end{array}$ & 2001 & Pampa \\
\hline & 45 & $28^{\circ} 56^{\prime} 31^{\prime \prime}$ & $54^{\circ} 20^{\prime} 02^{\prime \prime}$ & Pasture & - & Pampa \\
\hline & 46 & $28^{\circ} 55^{\prime} 48^{\prime \prime}$ & $54^{\circ} 20^{\prime} 29^{\prime \prime}$ & Native Vegetation & - & Pampa \\
\hline \multirow[t]{3}{*}{$\begin{array}{l}\text { Nova Esperança } \\
\text { do Sul (NS) - RS }\end{array}$} & 47 & $29^{\circ} 27^{\prime} 12^{\prime \prime}$ & $54^{\circ} 48^{\prime} 40^{\prime \prime}$ & $\begin{array}{l}\text { CLF (sorghum, pasture } \\
\text { and eucalyptus) }\end{array}$ & 2007 & Atlantic Forest \\
\hline & 48 & $29^{\circ} 27^{\prime} 33^{\prime \prime}$ & $54^{\circ} 49^{\prime} 17^{\prime \prime}$ & Pasture & - & Atlantic Forest \\
\hline & 49 & $29^{\circ} 27^{\prime} 31^{\prime \prime}$ & $54^{\circ} 49^{\prime} 18^{\prime \prime}$ & Native Vegetation & - & Atlantic Forest \\
\hline \multirow[t]{4}{*}{ Bagé (BA) - RS } & 50 & $31^{\circ} 22^{\prime} 11^{\prime \prime}$ & $54^{\circ} 00^{\prime} 11^{\prime \prime}$ & $\begin{array}{l}\text { CL (rice in summer and } \\
\text { L. multiflorum in win- } \\
\text { ter) }\end{array}$ & 2007 & Pampa \\
\hline & 51 & $31^{\circ} 22^{\prime} 01^{\prime \prime}$ & $54^{\circ} 00^{\prime} 28^{\prime \prime}$ & $\begin{array}{l}\text { Native Vegetation } \\
\text { (Campos), also used as } \\
\text { pasture }\end{array}$ & - & Pampa \\
\hline & 52 & $31^{\circ} 28^{\prime} 30^{\prime \prime}$ & $53^{\circ} 58^{\prime} 15^{\prime \prime}$ & $\begin{array}{l}\text { CLF (sorghum, pasture } \\
\text { and eucalyptus) }\end{array}$ & 2005 & Pampa \\
\hline & 53 & $31^{\circ} 19^{\prime} 17^{\prime \prime}$ & $54^{\circ} 00^{\prime} 12^{\prime \prime}$ & $\begin{array}{l}\text { CL (soy in summer and } \\
\text { L. multiflorum in win- } \\
\text { ter) }\end{array}$ & 2007 & Pampa \\
\hline \multirow[t]{3}{*}{$\begin{array}{l}\text { Capão do Leão } \\
\text { (CL) - RS }\end{array}$} & 54 & $31^{\circ} 49^{\prime} 57^{\prime \prime}$ & $52^{\circ} 28^{\prime} 28^{\prime \prime}$ & $\begin{array}{l}\text { Native Vegetation } \\
\text { (Campos), also utilized } \\
\text { as pasture }\end{array}$ & - & Pampa \\
\hline & 55 & $31^{\circ} 49^{\prime} 19^{\prime \prime}$ & $52^{\circ} 28^{\prime} 40^{\prime \prime}$ & $\begin{array}{l}\text { CL (soy in summer } \\
\text { and } L . \text { multiflorum } \\
\text { in winter) }\end{array}$ & 2007 & Pampa \\
\hline & 56 & $31^{\circ} 49^{\prime} 19^{\prime \prime}$ & $52^{\circ} 28^{\prime} 11^{\prime \prime}$ & $\begin{array}{l}\text { CL (soy or rice in } \\
\text { summer and } \\
\text { L. multiflorum in } \\
\text { winter) }\end{array}$ & 2007 & Pampa \\
\hline
\end{tabular}


Table 1. Continued.

\begin{tabular}{|c|c|c|c|c|c|c|}
\hline $\begin{array}{l}\text { City (Code) - } \\
\text { State }\end{array}$ & Point & Latitude & Longitude & Land use system & Established & Biome \\
\hline \multirow[t]{3}{*}{$\begin{array}{l}\text { Passo Fundo } \\
(\mathrm{PF})-\mathrm{RS}\end{array}$} & 57 & $28^{\circ} 13^{\prime} 32^{\prime \prime}$ & $52^{\circ} 24^{\prime} 30^{\prime \prime}$ & $\begin{array}{l}\text { CL (soy or corn in } \\
\text { summer and } \\
\text { L. multiflorum or oats } \\
\text { in the winter) }\end{array}$ & 1996 & Atlantic Forest \\
\hline & 58 & $28^{\circ} 13^{\prime} 31^{\prime \prime}$ & $52^{\circ} 24^{\prime} 28^{\prime \prime}$ & $\begin{array}{l}\text { CL (soy or corn in sum- } \\
\text { mer and L. multiflorum } \\
\text { or oats in winter) }\end{array}$ & 1996 & Atlantic Forest \\
\hline & 59 & $28^{\circ} 13^{\prime} 30^{\prime \prime}$ & $52^{\circ} 24^{\prime} 24^{\prime \prime}$ & Native Vegetation & - & Atlantic Forest \\
\hline
\end{tabular}

the methodology proposed by Ellert et al. (2008), which is briefly described below.

Cumulative soil mass was estimated for soil depths according to the following equations:

$M_{\text {soil }}=\sum{ }_{o}^{n} \rho \cdot z$,

where $M_{\text {soil }}$ is the cumulative soil mass, $\rho$ is the soil bulk density and $z$ is the soil depth interval.

The cumulative soil carbon stock for fixed depths is calculated by the following equations:

$\mathrm{SOC}_{\mathrm{FD}}=\sum{ }_{o}^{n} M_{\mathrm{soil}} \cdot[\mathrm{C}]$

where $\mathrm{SOC}_{\mathrm{FD}}$ is the cumulative soil carbon stock for fixed depths $z$ and $[\mathrm{C}]$ is the soil organic carbon concentration at the designated depth.

In each sampling site, encompassing different land uses, the lowest cumulative soil mass of soil depths were selected $\left(M_{\mathrm{ref}}\right)$ and the excess soil mass $\left(M_{\mathrm{ex}}\right)$ was calculated for all land uses (native forest, pasture and CPS) according to the following equation:

$M_{\mathrm{ex}}=M_{\mathrm{soil}}-M_{\mathrm{ref}}$,

for each land use the cumulative soil carbon stock for fixed mass was calculated by the following equation:

$\mathrm{SOC}_{\mathrm{FM}}=\mathrm{SOC}_{\mathrm{FD}}-M_{\mathrm{ex}} \cdot\left[\mathrm{C}_{\mathrm{ds}}\right]$,

where $\mathrm{SOC}_{\mathrm{FM}}$ is the cumulative soil carbon stock for a fixed mass and $\left[\mathrm{C}_{\mathrm{ds}}\right]$ is the soil carbon concentration in the deepest soil depth interval.

For the paired sites, changes in carbon stocks between current land use and native vegetation were obtained by comparing differences between the two stocks. The absolute difference $\left(\Delta S_{O} C_{a b s}\right)$ was expressed in $\mathrm{Mg} \mathrm{ha}^{-1}$ and the relative difference compared to the native vegetation was expressed in percentage $\left(\Delta \mathrm{SOC}_{\mathrm{rel}}\right)$.

For the regional survey of pasture soils, due to time and financial constraints, we were not able to sample soil from native vegetation near each pasture site. This poses a challenge because it is important to compare changes in the soil carbon stocks with the native vegetation as done in the paired study sites. In order to overcome the lack of original carbon soil stocks, we used estimates of native vegetation found in the literature. The most comprehensive of this type of survey was done by Bernoux et al. (2002), (denominated $\Delta \mathrm{SOC}_{\text {Bernoux }}$ ), which encompasses all the major biomes of the country. In order to make these comparisons, we assumed from Bernoux et al. (2002) the following soil carbon stocks according to the biome and soil type: Cerrado $\left(42 \mathrm{Mg} \mathrm{ha}^{-1}\right)$, Atlantic Forest (45 $\left.\mathrm{Mg} \mathrm{ha}^{-1}\right)$, and Pampas $\left(79 \mathrm{Mg} \mathrm{ha}^{-1}\right)$.

Using $\delta^{13} \mathrm{C}$ of the soil organic matter, we estimated the proportion of $\mathrm{C}_{3}\left(\mathrm{C}_{3 \mathrm{p}}\right)$ and $\mathrm{C}_{4}\left(\mathrm{C}_{4 \mathrm{p}}\right)$ carbon in the soil according to the following isotopic dilution equation:

$\mathrm{C}_{4 \mathrm{p}}=\frac{\delta^{13} \mathrm{C}_{\text {soil }}-\delta^{13} \mathrm{C}_{\mathrm{C}_{3}}}{\delta^{13} \mathrm{C}_{\mathrm{C}_{4}}-\delta^{13} \mathrm{C}_{\mathrm{C}_{3}}}$,

where $\mathrm{C}_{4 \mathrm{p}}$ is the proportion of $\mathrm{C}_{4}$ plants, $\delta^{13} \mathrm{C}_{\text {soil }}$ is the carbon isotopic composition of the soil's organic matter; $\delta^{13} \mathrm{C}_{\mathrm{C}_{3}}$ is the carbon isotopic composition of the $\mathrm{C}_{3}$ source, and the $\delta^{13} \mathrm{C}_{\mathrm{C}_{4}}$ is the carbon isotopic composition of the $\mathrm{C}_{4}$ source. In order to make inter-site comparisons straightforward, we used the lowest $\delta^{13} \mathrm{C}$ from native forest soils from our paired sites as the $\delta^{13} \mathrm{C}_{\mathrm{C}_{3}}(-26.7 \%$, and $-26.1 \%$, for $0-10 \mathrm{~cm}$ and $0-30 \mathrm{~cm}$, respectively); and the highest $\delta^{13} \mathrm{C}$ from the pasture regional survey as the $\delta^{13} \mathrm{C}_{\mathrm{C}_{4}}(-13.1 \%$, and $-13.7 \%$, for $0-10 \mathrm{~cm}$ and $0-30 \mathrm{~cm}$, respectively). The $\mathrm{C}_{3 \mathrm{p}}$ proportion was estimated as $1-\mathrm{C}_{4 \mathrm{p}}$ Relative proportions of $\mathrm{C}_{3}$ and $\mathrm{C}_{4}$ were not estimated at $60 \mathrm{~cm}$ soil depth because the decomposition process may increase $\delta^{13} \mathrm{C}$ values overestimating the $\mathrm{C}_{4}$ relative proportion.

As mentioned previously, we cannot be certain that the $\delta^{13} \mathrm{C}_{C 3}$ end-members chosen here are not free of $\mathrm{C}_{4}$ carbon. On the other hand, these values are similar to those found in undisturbed forest soils, in which the average values were $-27.0 \%$ and $-26.6 \%$, for $10 \mathrm{~cm}$ and $30 \mathrm{~cm}$, respectively (Martinelli et al., 1996; Sanaiotti et al., 2002). Additionally, we cannot be sure if the differences among land uses were due to the native vegetation replacement or these differences already existed between different areas. Braz et al. (2013) suggested that soil texture and bulk density at soil depths below 40 to $50 \mathrm{~cm}$ could be an indicator of soil carbon 
similarities among different areas. In Appendix A, we show the depth variability of soil bulk density (Fig. A1) and soil clay content (Fig. A2) of all paired sites in order to explore similarities among different land uses. We did not have statistical means to test for differences; however, it seems that in most sites, soil bulk densities tend to have similar values at higher depths (Fig. A1) and there were not great differences among land uses of a same paired site (Fig. A2). However, there are paired sites where there was a clear difference in soil bulk densities at deeper soil layers among different land uses and also there are paired sites where there were a significant difference in soil clay contents throughout soil profiles. As will be seen in the next topic, we tried to overcome this problem by including soil bulk density and soil texture as covariates in our statistical model; however, we cannot rule out the possibility that soil carbon stocks were different before the land use change have occurred, especially in those places where bulk density and soil texture varies among land uses. Finally, due to the lack of reliable information of our paired sites we do not know precisely which year a given conversion occurred. Additionally, we have used a point-in-time measurement, which means that we did not follow changes in carbon soil stocks through time. As a consequence, we do not know if the soil organic matter achieved a new steady-state equilibrium or not. This fact means that our results should be interpreted with caution (Sanderman and Baldock, 2010).

\subsection{Statistical analysis}

The $\delta^{13} \mathrm{C}$ followed a normal distribution, but soil carbon stocks must be transformed using Box-Cox techniques to achieve normality. All statistical tests were performed using transformed soil carbon stocks, but non-transformed values were used to report average values.

For the paired sites, differences between land uses (native vegetation, CPS and pasture) were tested with ANCOVA, with the dependent variables being transformed carbon soil stocks or $\delta^{13} \mathrm{C}$ values at the soil depth intervals of $0-10 \mathrm{~cm}$, $0-30 \mathrm{~cm}$, and $0-60 \mathrm{~cm}$; the independent variables were land use type. As MAT (mean annual temperature), MAP (mean annual precipitation), soil density and soil texture may influence carbon soil stocks and $\delta^{13} \mathrm{C}$ values, these were also included in the model as co-variables. The Tukey Honest Test for unequal variance was used as a post-hoc test. In order to determine whether changes in carbon stocks between current land use and native vegetation $\left(\Delta \mathrm{SOC}_{\mathrm{abs}}\right.$ and $\left.\Delta \mathrm{SOC}_{\mathrm{rel}}\right)$ were statistically significant, we used a one-sample $t$ test, where the null hypothesis was that the population mean was equal to zero.

As our database encompasses different biomes, climates, and land management, all tests were reported as significant at a level of $10 \%$. Statistical tests were performed using a STATISTICA11 package.

\section{Results}

\subsection{Paired study sites}

\subsubsection{Stable carbon isotopic composition}

It is important to point out that in Ponta Grossa in Paraná State, and Bagé and Capão do Leão in Rio Grande do Sul State, the native vegetation is composed of $\mathrm{C}_{4}$ grasses or a mixture of $\mathrm{C}_{4}$ and $\mathrm{C}_{3}$ plants. The $\delta^{13} \mathrm{C}$ of the topsoil $(0-10 \mathrm{~cm})$ of these sites was equal to $-15 \%$ o, $-21.2 \%$, and $-15.4 \%$, respectively. $\delta^{13} \mathrm{C}$ data from these sites were not included in the discussion that follows.

The average $\delta^{13} \mathrm{C}$ of the $\mathrm{C}_{3}$ native vegetation topsoil $(0-10 \mathrm{~cm})$ obtained by averaging values from $0-5 \mathrm{~cm}$ and $5-10 \mathrm{~cm}$ of soil depth intervals in the paired study sites (Table 2) was equal to $-25.4 \%$, increasing to $-19.6 \%$ in the crop-pasture systems (CPS) and to $-17.7 \%$ in the pasture soil $\left(F_{(2.53)}=16.42, p<0.01\right)$. The post-hoc Tukey test showed that only the average $\delta^{13} \mathrm{C}$ of the $\mathrm{C}_{3}$ native vegetation soil was significantly different than pasture and CPS systems $(p<0.01)$. The average $\delta^{13} \mathrm{C}$ of the $\mathrm{C}_{3}$ native vegetation soil in the paired sites was also significantly lower than pasture and CPS soils $\left(F_{(2.53)}=10.76, p<0.01\right)$ at the $0-30 \mathrm{~cm}$ soil depth interval (Table 3).

In the paired study sites, the average proportion of $\mathrm{C}_{4}$ plants $\left(\mathrm{C}_{4 \mathrm{p}}\right)$ was approximately 0.10 in the native vegetation topsoil $(0-10 \mathrm{~cm})$, increasing to 0.52 in CPS and reaching a maximum of approximately 0.66 in pasture soils (Table 2 ). In the $0-30 \mathrm{~cm}$ depth interval, the $\mathrm{C}_{4 \mathrm{p}}$ in the native vegetation soils was approximately 0.17 , increasing to approximately 0.60 in CPS and again reaching a maximum of approximately 0.63 in pasture soils (Table 3 ). The fact that there is $\mathrm{C}_{4}$ carbon especially in the topsoil of native vegetation is an indication that not all native forests were primary forests.

There was great depth variability in the $\delta^{13} \mathrm{C}$ of soils under native vegetation (Fig. 2). This was in part due to the fact that three sites located in the southern region of the country were natural $\mathrm{C}_{4}$ grasslands - Ponta Grossa (PG), Bagé (BA) and Capão do Leão (CL). Ponta Grossa had the highest soil $\delta^{13} \mathrm{C}$ in all depths, indicating that these soils are almost entirely composed of $\mathrm{C}_{4}$ carbon (Fig. 3). Capão do Leão had lower $\delta^{13} \mathrm{C}$ than Ponta Grossa, which is still indicative of a high $\mathrm{C}_{4}$ presence (Fig. 2). On the other hand, Bagé had the lowest $\delta^{13} \mathrm{C}$ among all three grassland sites, showing a mixture of $\mathrm{C}_{3}$ and $\mathrm{C}_{4}$ vegetation in their soils. The presence of $\mathrm{C}_{4}$ carbon increases with depth in this latter site (Fig. 2). Two other sites, Arroio dos Ratos (AR) and Tuparacetã (TU), also showed an increasing contribution of $\mathrm{C}_{4}$ carbon with depth; however, in the soil surface both sites had characteristic $\delta^{13} \mathrm{C}$ from $\mathrm{C}_{3}$ carbon (Fig. 2). At the other end of the spectrum, showing typical forest depth profiles, there is São Carlos (SC), Cafeara (CS), Iporã (IP), and Nova Esperança do Sul (NS) soil profiles (Fig. 2). 
Table 2. Mean, standard-deviation (Std. Dev.), minimum and maximum for $\delta^{13} \mathrm{C}, \mathrm{C}_{3}$ proportion $\left(\mathrm{C}_{3}\right), \mathrm{C}_{4}$ proportion $\left(\mathrm{C}_{4}\right)$, and carbon stocks $\left(\mathrm{SOC}_{\text {stock }}\right)$ at $0-10 \mathrm{~cm}$ soil depth layer for forest, crop-livestock systems and pasture soils at the paired study sites. $\Delta \mathrm{SOC}$ abs is the difference between the carbon soil stock of native vegetation and crop-livestock systems and pasture soils obtained in the paired study sites. $\Delta \mathrm{SOC}_{\mathrm{rel}}$ is the same difference expressed as percentage. Carbon losses are indicated by a minus sign (-).

\begin{tabular}{|c|c|c|c|c|c|}
\hline & \multicolumn{5}{|c|}{ Native Vegetation $(0-10 \mathrm{~cm})$} \\
\hline & $N$ & Mean & Std. Dev. & Minimum & Maximum \\
\hline$\delta^{13} \mathrm{C}(\% \circ)^{*}$ & 13 & -25.4 & 1.4 & -26.8 & -22.9 \\
\hline $\mathrm{C}_{4} *$ & 13 & 0.10 & 0.11 & 0 & 0.29 \\
\hline $\mathrm{C}_{3} *$ & 13 & 0.90 & 0.11 & 0.71 & 1.00 \\
\hline \multirow[t]{3}{*}{$\mathrm{SOC}_{\text {stock }}\left(\mathrm{Mg} \mathrm{ha}^{-1}\right)$} & 16 & 33.4 & 14.7 & 12.7 & 57.7 \\
\hline & \multicolumn{5}{|c|}{ Crop-livestock $(0-10 \mathrm{~cm})$} \\
\hline & $N$ & Mean & Std. Dev. & Minimum & Maximum \\
\hline$\delta^{13} \mathrm{C}(\% o)$ & 27 & -19.6 & 2.6 & -23.6 & -13.7 \\
\hline $\mathrm{C}_{4}$ & 27 & 0.52 & 0.2 & 0.24 & 1 \\
\hline $\mathrm{C}_{3}$ & 27 & 0.48 & 0.2 & 0 & 0.76 \\
\hline $\mathrm{SOC}_{\text {stock }}\left(\mathrm{Mg} \mathrm{ha}^{-1}\right)$ & 27 & 26.3 & 11.85 & 8.06 & 44.79 \\
\hline$\Delta \mathrm{SOC}_{\mathrm{abs}}\left(\mathrm{Mgha}^{-1}\right)$ & 27 & -7.53 & 9.81 & -29.76 & 12.13 \\
\hline \multirow[t]{3}{*}{$\Delta \mathrm{SOC}_{\mathrm{rel}}(\%)$} & 27 & -20 & 28 & -53 & 44 \\
\hline & \multicolumn{5}{|c|}{ Pasture $(0-10 \mathrm{~cm})$} \\
\hline & $N$ & Mean & Std. Dev. & Minimum & Maximum \\
\hline$\delta^{13} \mathrm{C}(\%)$ & 13 & -17.7 & 2.2 & -23.1 & -14.5 \\
\hline $\mathrm{C}_{4}$ & 13 & 0.66 & 0.17 & 0.28 & 0.94 \\
\hline $\mathrm{C}_{3}$ & 13 & 0.34 & 0.17 & 0.06 & 0.72 \\
\hline $\mathrm{SOC}_{\text {stock }}\left(\mathrm{Mg} \mathrm{ha}^{-1}\right)$ & 13 & 24.5 & 14.5 & 6 & 47.7 \\
\hline$\Delta \mathrm{SOC}_{\mathrm{abs}}\left(\mathrm{Mg} \mathrm{ha}^{-1}\right)$ & 13 & -8.3 & 9.2 & -24 & 8.8 \\
\hline$\Delta \mathrm{SOC}_{\mathrm{rel}}(\%)$ & 13 & -26 & 26 & -67 & 25 \\
\hline
\end{tabular}

* Ponta Grossa, Bagé and Capão do Leão, which are predominantly $\mathrm{C}_{4}$ sites, were not included.

The $\delta^{13} \mathrm{C}$ in pasture paired site soil profiles were also highly variable, reflecting constant changes in land use. There are profiles like Ponta Grossa (PG) in which the original vegetation is composed of $\mathrm{C}_{4}$ plants; therefore, there was not much change between native grasslands and introduced $\mathrm{C}_{4}$ grasses (Fig. 2). The São Carlos profile (SC) is also a good example of the predominant $\mathrm{C}_{4}$ presence (Fig. 2), but in this case, it probably denotes the presence of a cultivated pasture, since the original forest has a clear $\mathrm{C}_{3}$ signal throughout the entire profile (Fig. 2). On the other hand, there are profiles, which, although they have been converted to pasture, still show a large contribution of $\mathrm{C}_{3}$ plants. These profiles are best illustrated by Sete Lagoas (SL) and Iporã (IP) (Fig. 2). These profiles show a higher proportion of $\mathrm{C}_{4}$ at the surface, with increasing contributions of $\mathrm{C}_{3}$ plants at deeper depths (Fig. 2). Finally, the soil profiles in Coronel Xavier (CX), Campo Mourão (CM) and Nova Esperança do Sul (NS) show a mixture of $\mathrm{C}_{3}$ and $\mathrm{C}_{4}$ carbon throughout the soil depth, with $\delta^{13} \mathrm{C}$ varying from approximately -18 to $-16 \%$ (Fig. 2).

\subsubsection{Soil carbon stocks}

The average carbon stock of the native vegetation soils corrected for soil mass in the topsoil $(0-10 \mathrm{~cm})$ was $29.0 \mathrm{Mg} \mathrm{ha}^{-1}$ decreasing $\left(F_{(2.49)}=4.08, p=0.02\right)$ to $22.6 \mathrm{Mg} \mathrm{ha}^{-1}$ in the CPS and to $20.9 \mathrm{Mg} \mathrm{ha}^{-1}$ in pasture soils (Table 2). In the $0-30 \mathrm{~cm}$ of the soil depth interval, the carbon stock corrected for soil mass of the native vegetation soils was $63.6 \mathrm{Mg} \mathrm{ha}^{-1}$ decreasing again $\left(F_{(2.49)}=2.79\right.$, $p=0.07$ ) to $53.4 \mathrm{Mg} \mathrm{ha}^{-1}$ in the CPS and to $52.1 \mathrm{Mg} \mathrm{ha}^{-1}$ in pasture soils (Table 3). Finally, in the $0-60 \mathrm{~cm}$ of the soil depth interval, the carbon stock corrected to soil mass was $91.8 \mathrm{Mg} \mathrm{ha}^{-1}$ in the native vegetation, $85.8 \mathrm{Mg} \mathrm{ha}^{-1}$ and $83.6 \mathrm{Mg} \mathrm{ha}^{-1}$ in the CPS and pasture soils, respectively (Table 4). However, differing from the other two depth intervals, the differences in the soil carbon stocks between land uses were not statistically different.

Except for the $0-60 \mathrm{~cm}$ soil depth interval, most of the paired sites either for CPS or pasture soils showed a decrease in carbon stocks compared to native vegetation areas (Fig. 3). As a consequence, there was a net loss of carbon stocks between native vegetation and 
Table 3. Mean, standard-deviation (Std. Dev.), minimum and maximum for $\delta^{13} \mathrm{C}, \mathrm{C}_{3}$ proportion, $\mathrm{C}_{4}$ proportion, and carbon stocks $\left(\mathrm{SOC}_{\text {stock }}\right)$ at $0-30 \mathrm{~cm}$ soil depth layer for forest, crop-livestock systems and pasture soils at paired study sites. $\Delta \mathrm{SOC}$ abs is the difference between the carbon soil stock of native vegetation and crop-livestock systems and pasture soils obtained in the paired study sites. $\Delta \mathrm{SOC}_{\mathrm{rel}}$ is the same difference expressed as percentage. Carbon losses are indicated by a minus sign (-).

\begin{tabular}{|c|c|c|c|c|c|}
\hline & \multicolumn{5}{|c|}{ Forest $(0-30 \mathrm{~cm})$} \\
\hline & $N$ & Mean & Std. Dev. & Minimum & Maximum \\
\hline$\delta^{13} \mathrm{C}(\% \circ)^{*}$ & 13 & -24 & 1.7 & -26.1 & -20.3 \\
\hline $\mathrm{C}_{4}{ }^{*}$ & 13 & 0.17 & 0.14 & 0.0 & 0.26 \\
\hline $\mathrm{C}_{3} *$ & 13 & 0.83 & 0.14 & 0.74 & 1.00 \\
\hline \multirow[t]{3}{*}{$\mathrm{SOC}_{\text {stock }}\left(\mathrm{Mg} \mathrm{ha}^{-1}\right)$} & 16 & 72.3 & 33.2 & 27.3 & 123 \\
\hline & \multicolumn{5}{|c|}{ Crop-livestock $(0-30 \mathrm{~cm})$} \\
\hline & $N$ & Mean & Std. Dev. & Minimum & Maximum \\
\hline$\delta^{13} \mathrm{C}(\%)$ & 27 & -18.9 & 2.5 & -22.5 & -14 \\
\hline $\mathrm{C}_{4}$ & 27 & 0.58 & 0.21 & 0.29 & 1 \\
\hline $\mathrm{C}_{3}$ & 27 & 0.42 & 0.21 & 0 & 0.71 \\
\hline $\operatorname{SOC}_{\text {stock }}\left(\mathrm{Mg} \mathrm{ha}^{-1}\right)$ & 27 & 61.1 & 28.6 & 15.5 & 115 \\
\hline$\Delta \mathrm{SOC}_{\mathrm{abs}}\left(\mathrm{Mgha}^{-1}\right)$ & 27 & -11.9 & 22.2 & -55.7 & 36.4 \\
\hline \multirow[t]{3}{*}{$\Delta \mathrm{SOC}_{\mathrm{rel}}(\%)$} & 27 & -15 & 27 & -60 & 52 \\
\hline & \multicolumn{5}{|c|}{ Pasture $(0-30 \mathrm{~cm})$} \\
\hline & $N$ & Mean & Std. Dev. & Minimum & Maximum \\
\hline$\delta^{13} \mathrm{C}(\%)$ & 13 & -18.3 & 2.4 & -23.5 & -14.9 \\
\hline $\mathrm{C}_{4}$ & 13 & 0.63 & 0.19 & 0.22 & 0.93 \\
\hline $\mathrm{C}_{3}$ & 13 & 0.37 & 0.19 & 0.07 & 0.78 \\
\hline $\operatorname{SOC}_{\text {stock }}\left(\mathrm{Mg} \mathrm{ha}^{-1}\right)$ & 13 & 59.5 & 31.4 & 15.9 & 100.9 \\
\hline$\Delta \mathrm{SOC}_{\mathrm{abs}}\left(\mathrm{Mgha}^{-1}\right)$ & 13 & -12.2 & 16.5 & -36.5 & 12.4 \\
\hline$\Delta \mathrm{SOC}_{\mathrm{rel}}(\%)$ & 13 & -16 & 20 & -59 & 14 \\
\hline
\end{tabular}

* Ponta Grossa, Bagé and Capão do Leão, which are predominantly $\mathrm{C}_{4}$ sites, were not included.

current land uses in the soil surface (Tables 2 and 3 ). For the topsoil $(0-10 \mathrm{~cm})$, in the forest-CPS pairs both the $\Delta \mathrm{SOC}_{\mathrm{abs}}=-7.5 \mathrm{Mg} \mathrm{ha}^{-1}(t=-4.35, p<0.01)$, and the $\Delta \mathrm{SOC}_{\mathrm{rel}}=-18 \%(t=-4.14 . \quad p<0.01)$ were statistically significant, and the same was true for the 0 $30 \mathrm{~cm}$ depth interval, where the $\Delta \mathrm{SOC}_{\mathrm{abs}}=-11.6 \mathrm{Mg} \mathrm{ha}^{-1}$ $(t=-2.94, p=0.01)$ and the $\Delta \mathrm{SOC}_{\mathrm{rel}}=-16 \%(t=-2.96$, $p=0.01)$. In the forest-pasture pair sites also both the $\Delta \mathrm{SOC}_{\mathrm{abs}}=-7.5 \mathrm{Mgha}^{-1}(t=-3.10, p<0.01)$ and the $\Delta \mathrm{SOC}_{\mathrm{rel}}=-28 \%(t=-3.64, p<0.01)$ were statistically significant. For the $0-30 \mathrm{~cm}$ depth interval, losses in the forest-pasture pair sites were $\Delta \mathrm{SOC}_{\mathrm{abs}}=-11.0 \mathrm{Mg} \mathrm{ha}^{-1}$ $(t=-2.49, \quad p=0.03)$, and $\Delta \mathrm{SOC}_{\mathrm{rel}}=-16 \% \quad(t=2.71$, $p=0.02)$. For the $0-60 \mathrm{~cm}$ depth interval, neither $\Delta \mathrm{SOC}_{\mathrm{abs}}$ nor $\Delta \mathrm{SOC}_{\text {rel }}$ were statistically significant (Table 4 ).

\subsection{Regional survey of pasture soils}

\subsubsection{Stable carbon isotopic composition}

There was wide variability of the $\delta^{13} \mathrm{C}$ of pasture soils of the regional survey with soil depth (Fig. 4), and consequently in the proportion of $\mathrm{C}_{4}$ carbon incorporated into the soil. The average $\delta^{13} \mathrm{C}$ of pasture soil at $0-10 \mathrm{~cm}$ depth interval was $-18.7 \pm 2.8 \%$, with the average contribution of $\mathrm{C}_{4}$ carbon to the soil being equal to $0.58 \pm 0.20$. The average $\delta^{13} \mathrm{C}$ of pasture soils at $0-30 \mathrm{~cm}$ was similar and equal to $-19.3 \pm 2.7 \%$ and $\mathrm{C}_{4}$ carbon contribution to the soil decreased slightly to $0.54 \pm 0.20$ (Table 5). No significant correlation was found between the $\mathrm{C}_{4}$ carbon contribution, and climatic variables like MAT and MAP nor soil texture.

\subsubsection{Soil carbon stocks}

At the depth interval $0-10 \mathrm{~cm}$ the average total carbon soil stock was equal to $21.6 \pm 10.7 \mathrm{Mg} \mathrm{ha}^{-1}$, with values varying from $<10 \mathrm{Mg} \mathrm{ha}^{-1}$ up to $>40 \mathrm{Mg} \mathrm{ha}^{-1}$ (Fig. 5). The average total carbon soil stock at the depth interval $0-30 \mathrm{~cm}$ was equal to $50.6 \pm 23.2 \mathrm{Mg} \mathrm{ha}^{-1}$, with values varying from $<20 \mathrm{Mg} \mathrm{ha}^{-1}$ up to $>100 \mathrm{Mg} \mathrm{ha}^{-1}$ (Fig. 5).

Compared with carbon stocks at soil depth interval 0-30 cm from Bernoux et al. (2002), the absolute change in the soil carbon stocks from pastures compared to carbon stocks of native vegetation $\left(\triangle \mathrm{SOC}_{\mathrm{Bernoux}-\mathrm{abs}}\right)$ were mostly 


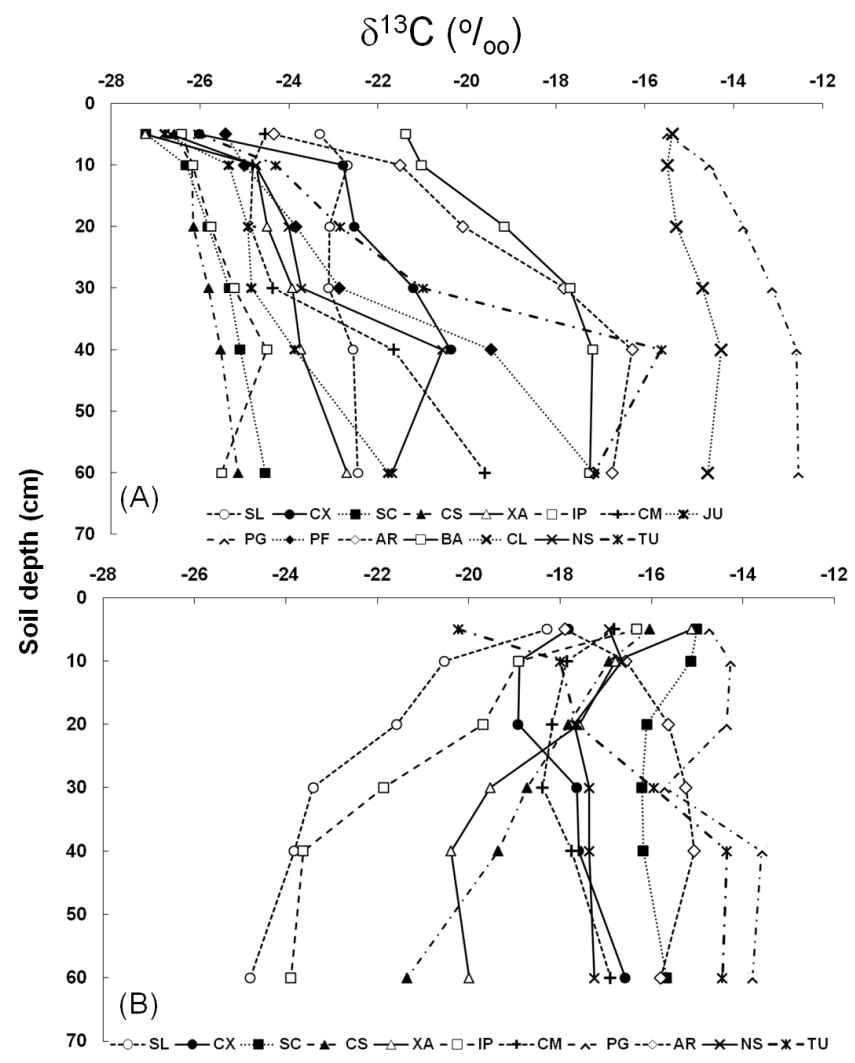

Fig. 2. Variability of $\delta^{13} \mathrm{C}$ of soil organic matter with soil depth of native forests (A) and pastures of the paired study sites (B). Legends are name abbreviations of sampling sites according to Table 1.

positive (Fig. 6), indicating an average gain of carbon of $6.7 \mathrm{Mg} \mathrm{ha}^{-1}(t=3.07, p=0.01)$ compared to the native vegetation (Table 5). In relative terms $\left(\Delta \mathrm{SOC}_{\text {Bernoux-rel }}\right)$, there was a gain of $15 \%(t=3.23, p<0.01)$.

\subsubsection{Controls of carbon soil stocks}

Many variables may control carbon soil stocks. At the regional level, climatic variables like temperature and rainfall are important, while at the local level, soil properties like texture, density and fertility are also key variables (Jobbágy and Jackson, 2000; Eclesia et al., 2012; Saiz et al., 2012). We used stepwise regression to choose the best set of variables that control soil carbon stocks. Among all parameters for both soil depth intervals $(10 \mathrm{~cm}$ and $30 \mathrm{~cm})$, the higher adjusted correlation was obtained using the mean annual temperature (MAT) and soil sand content as a predictor of variables.

The adjusted correlation coefficient $\left(r_{\text {adj }}^{2}\right)$ for carbon was approximately $0.50\left(F_{(2112)}=50.42, p<0.01\right)$, which means that half of the variance of carbon soil stocks can be explained by MAT and sand content.

$\mathrm{SOC}_{0-30}=138.27-2.72 \cdot(\mathrm{MAT})-0.46 \cdot(\mathrm{SAND})$,

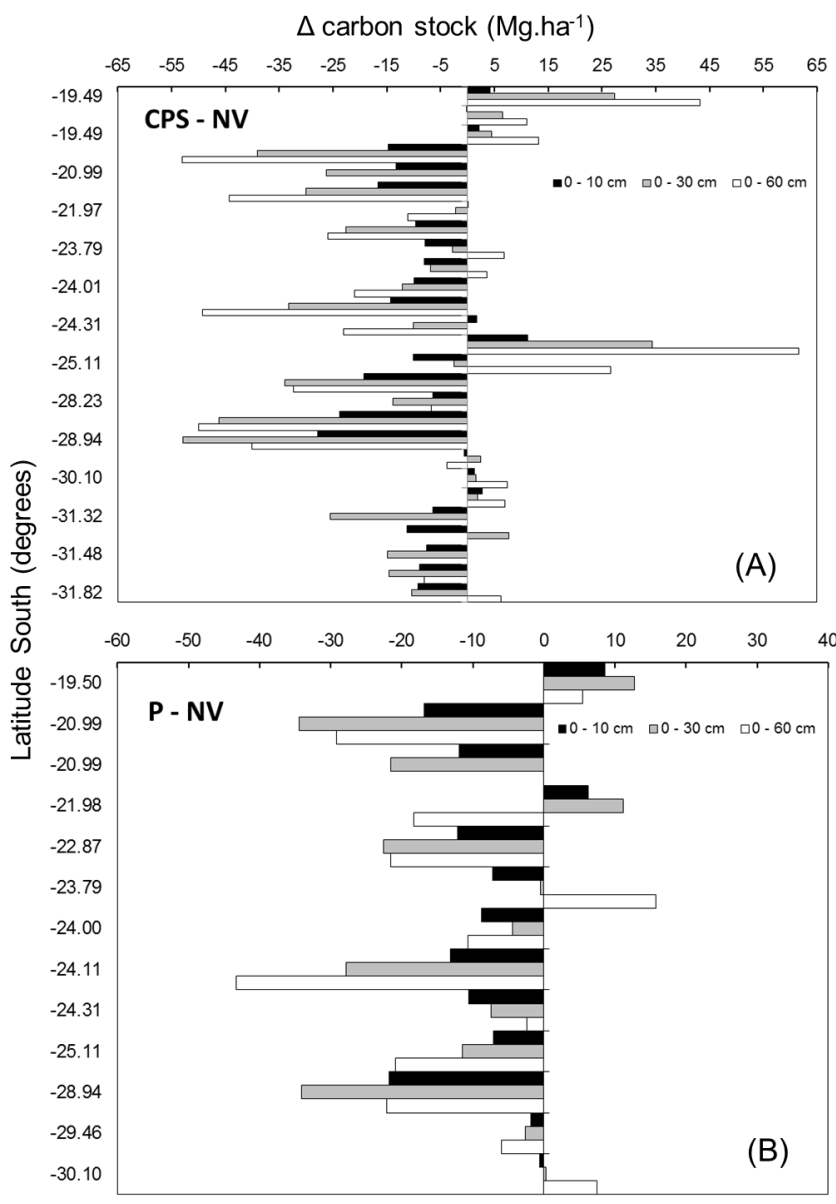

Fig. 3. Absolute difference of carbon soil stocks between different depth intervals: (A) crop-livestock systems (CPS) and native vegetation $(\mathrm{NV})$; and $(\mathrm{B})$ pasture $(\mathrm{P})$ and native vegetation $(\mathrm{NV})$ at different paired study sites. Losses are indicated by a minus sign $(-)$.

where $\mathrm{SOC}_{0-30}$ represent the soil carbon stocks expressed as $\mathrm{Mg} \mathrm{ha}^{-1}$ at $30 \mathrm{~cm}$ soil depth, MAT represents the mean annual temperature expressed in Celsius, and SAND represents the soil sand content expressed in percentage.

Figure 7 shows the surface area produced by Eq. (7) in the upper panel, and the observed and predicted values of carbon soil stock at $30 \mathrm{~cm}$ depth as an example in the lower panel. As found by Post et al. (1982), there is a tendency for colder regions and lower sand content to contain higher soil stocks than warmer regions with sandy soils (Fig. 7).

\section{Discussion}

\subsection{Soil carbon stocks of the native vegetation in the paired sites}

The paired sites' average soil carbon stocks at the depth interval $0-30 \mathrm{~cm}$, correcting for soil mass for the native 
Table 4. Mean, standard deviation (Std. Dev.), minimum and maximum for carbon stocks $\left(\mathrm{SOC}_{\text {stock }}\right)$ at $0-60 \mathrm{~cm}$ soil depth layer for forest, crop-livestock systems and pasture soils at paired study sites. $\Delta \mathrm{SOC}_{\mathrm{abs}}$ is the difference between the carbon soil stock of native vegetation and crop-livestock systems and pasture soils obtained in the paired study sites. $\Delta \mathrm{SOC}_{\mathrm{rel}}$ is the same difference expressed as percentage. Carbon losses are indicated by a minus sign (-).

\begin{tabular}{|c|c|c|c|c|c|}
\hline \multirow[b]{3}{*}{$\delta^{13} \mathrm{C}(\% o)^{*}$} & \multicolumn{5}{|c|}{ Forest $(0-60 \mathrm{~cm})$} \\
\hline & $N$ & Mean & Std. Dev. & Minimum & Maximum \\
\hline & 13 & -22.7 & 2.4 & -25.7 & -18.4 \\
\hline \multirow[t]{3}{*}{$\mathrm{SOC}_{\text {stock }}\left(\mathrm{Mg} \mathrm{ha}^{-1}\right)$} & 16 & 91.8 & 48.0 & 23.6 & 186.3 \\
\hline & \multicolumn{5}{|c|}{ Crop-livestock $(0-60 \mathrm{~cm})$} \\
\hline & $N$ & Mean & Std. Dev. & Minimum & Maximum \\
\hline$\delta^{13} \mathrm{C}(\% \circ)$ & 27 & -18.4 & 2.9 & -23.1 & -13.6 \\
\hline $\operatorname{SOC}_{\text {stock }}\left(\mathrm{Mg} \mathrm{ha}^{-1}\right)$ & 27 & 85.8 & 44.5 & 20.8 & 176.0 \\
\hline$\Delta \mathrm{SOC}_{\mathrm{abs}}\left(\mathrm{Mg} \mathrm{ha}^{-1}\right)$ & 27 & -7.9 & 29.9 & -52.9 & 61.6 \\
\hline \multirow[t]{3}{*}{$\Delta \mathrm{SOC}_{\mathrm{rel}}(\%)$} & 27 & -5.0 & 30.0 & -56.0 & 59.0 \\
\hline & \multicolumn{5}{|c|}{ Pasture $(0-60 \mathrm{~cm})$} \\
\hline & $N$ & Mean & Std. Dev. & Minimum & Maximum \\
\hline$\delta^{13} \mathrm{C}(\% \circ)$ & 13 & -18.5 & 2.8 & -23.0 & -14.3 \\
\hline $\mathrm{SOC}_{\text {stock }}\left(\mathrm{Mg} \mathrm{ha}^{-1}\right)$ & 13 & 83.6 & 44.7 & 25.2 & 151.4 \\
\hline$\Delta \mathrm{SOC}_{\mathrm{abs}}\left(\mathrm{Mg} \mathrm{ha}^{-1}\right)$ & 13 & -12.6 & 16.5 & -43.3 & 15.7 \\
\hline$\Delta \mathrm{SOC}_{\mathrm{rel}}(\%)$ & 13 & -8.0 & 29.0 & -46 & 66.0 \\
\hline
\end{tabular}

Table 5. Mean, standard deviation (Std. Dev.), minimum, and maximum for $\delta^{13} \mathrm{C}, \mathrm{C}_{3}$ proportion, $\mathrm{C}_{4}$ proportion, and carbon stocks

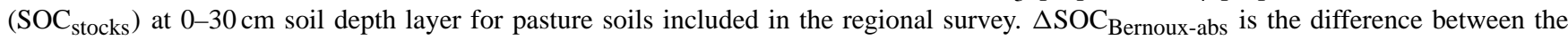
carbon soil stock of native vegetation obtained by Bernoux et al. (2002) and pasture soils. $\Delta$ SOC $_{\text {Bernoux-rel }}$ is the same difference expressed as percentage.

\begin{tabular}{lrrrrr}
\hline & $N$ & Mean & Std. Dev. & Minimum & Maximum \\
\hline$\delta^{13} \mathrm{C}$ & 103 & -19.3 & 2.7 & -26.0 & -13.3 \\
$\mathrm{C}_{3}$ & 103 & 0.46 & 0.20 & 0.04 & 0.95 \\
$\mathrm{C}_{4}$ & 103 & 0.54 & 0.20 & 0.05 & 0.96 \\
SOC $_{\text {stocks }}\left(\mathrm{Mg} \mathrm{ha}^{-1}\right)$ & 103 & 50.6 & 23.3 & 11.2 & 142.6 \\
$\Delta$ SOC $_{\text {Bernoux-abs }}\left(\mathrm{Mg} \mathrm{ha}^{-1}\right)$ & 103 & 6.7 & 22.1 & -32.8 & 97.4 \\
$\Delta \operatorname{SOC}_{\text {Bernoux-rel }}(\%)$ & 103 & 15.0 & 45.0 & -6.0 & 141.0 \\
\hline
\end{tabular}

vegetation, was equal to approximately $63.6 \mathrm{Mg} \mathrm{ha}^{-1}$ (Table 3). This value is similar to the carbon soil stock for soils with high activity clay (HAC) considering the "moist tropical climate" domain adopted by the IPCC that encompasses most of Brazil, except for the Amazon region and the northeast Caatinga (IPCC, 2006). On the other hand, the average carbon soil stock found in this study for native vegetation in the paired sites is higher than the carbon stock for soils with low activity clay (LAC) considering the same climate region, which was equal to $47 \mathrm{Mg} \mathrm{ha}^{-1}$ (IPCC, 2006). Compared with carbon soil stocks estimated for different biomes and soil types of Brazil by Bernoux et al. (2002), the average carbon stock found in this study for native vegetation was higher than the soil carbon stock found for the
Cerrado (44 $\mathrm{Mg} \mathrm{ha}^{-1}$ ) and "seasonal semi-deciduous forest" $\left(49 \mathrm{Mg} \mathrm{ha}^{-1}\right)$ biomes considered HAC soils. On the other hand, our paired study sites also includes four sites that belong to the southern savanna biome (Fig. 1), and for this region Bernoux et al. (2002) estimated carbon soil stocks varying from approximately 71 to $88 \mathrm{Mg} \mathrm{ha}^{-1}$ for LAC and HAC soils, respectively, which are larger than the average carbon stock of native vegetation found in this study.

\subsection{Changes in carbon stocks with soil cultivation - plot-level paired sites}

The results found in our plot-level paired study sites confirmed the tendency found in regional and global studies of soil carbon losses with soil cultivation 

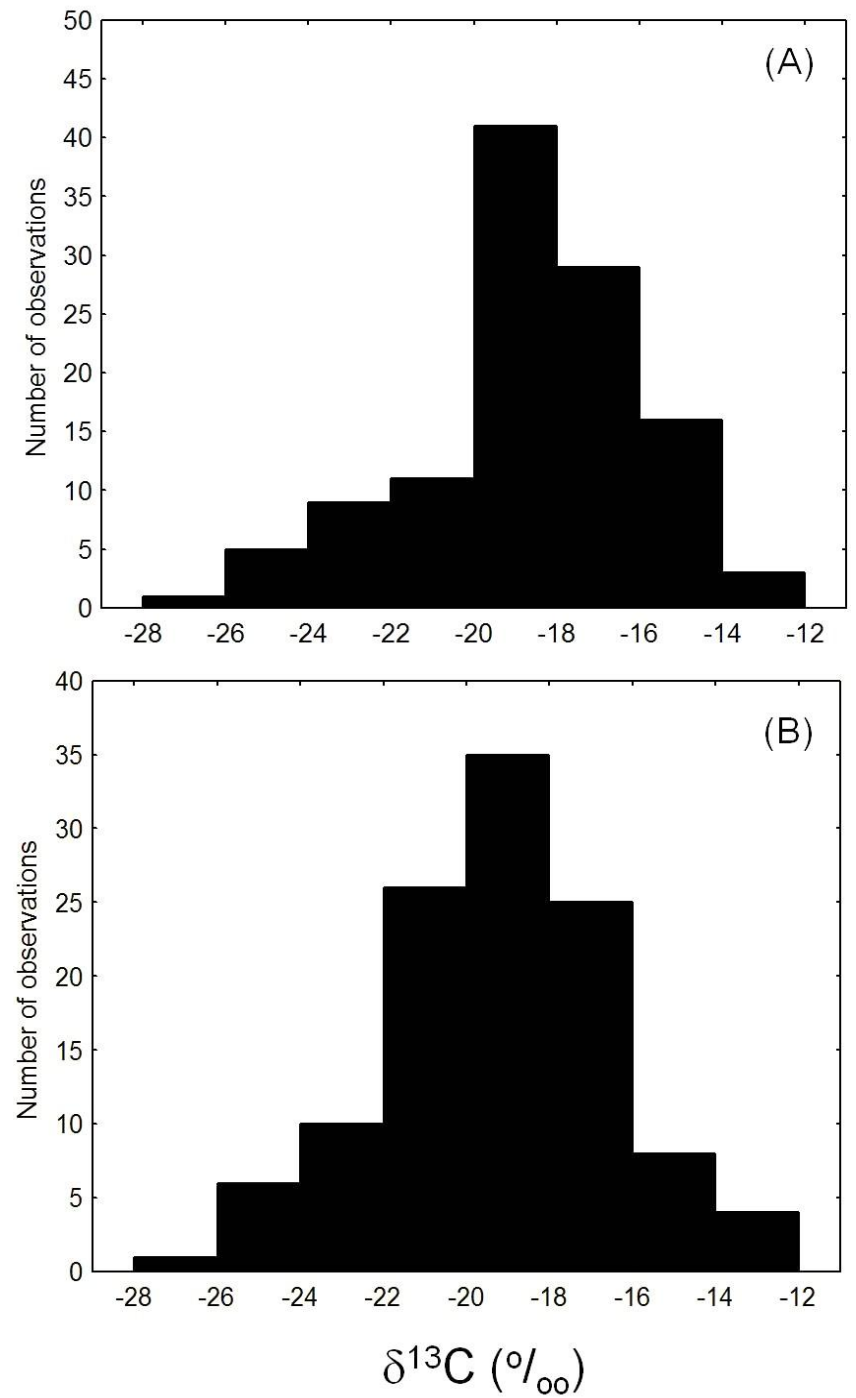

Fig. 4. Histograms of (A) the $\delta^{13} \mathrm{C}$ of soil organic matter in the pasture sites at $0-10 \mathrm{~cm}$ depth interval and (B) at $0-30 \mathrm{~cm}$ depth interval.

(Davidson and Ackerman, 1993; Amundson, 2001; Guo and Gifford, 2002; Ogle et al., 2005; Maia et al., 2010; Don et al., 2011). The net balance for the native vegetationpasture conversion was $-7.5 \mathrm{Mg} \mathrm{ha}^{-1}$ for carbon $(-28 \%)$ and $-11.0 \mathrm{Mg} \mathrm{ha}^{-1}(-16 \%)$, for $0-10 \mathrm{~cm}$ and for $0-30 \mathrm{~cm}$ depth intervals, respectively (Tables 2 and 3). These losses are similar to those reported by Don et al. (2011) who found through a meta-analysis that the native vegetation-pasture conversion was $-12.6 \mathrm{Mg} \mathrm{ha}^{-1}$ at $0-30 \mathrm{~cm}$ depth, which corresponds to a relative loss of $-12 \%$, a little higher than the $-16 \%$ found in this study.

On the other hand, the results found in our paired sites (Fig. 3) also confirmed other studies that involved plot-scale comparisons, especially on pasture soils, that showed that depending on local conditions, the soil carbon stocks may in-
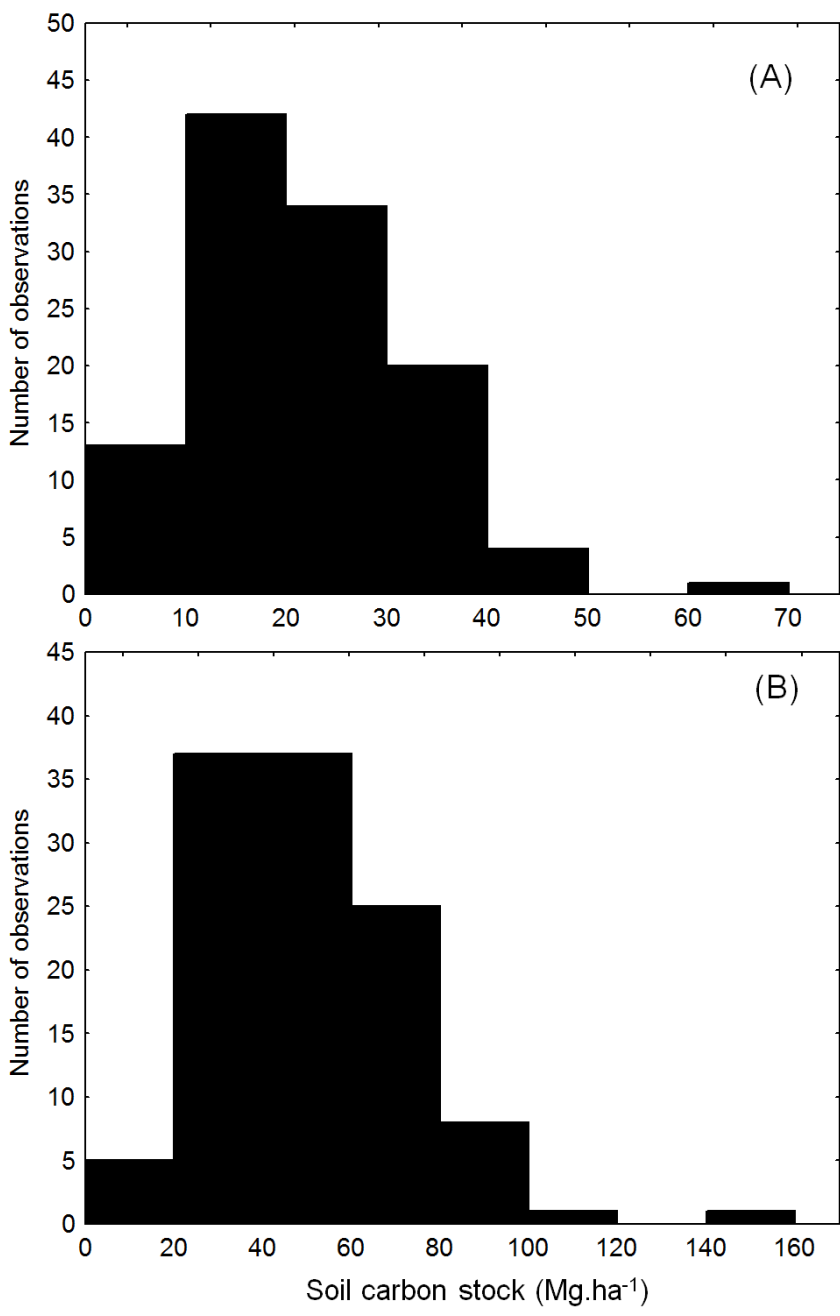

Fig. 5. Histograms of (A) soil carbon stock in the regional pasture sites at $0-10 \mathrm{~cm}$ depth interval and (B) at 0-30 $\mathrm{cm}$ depth interval.

crease compared to the local native vegetation (Guo and Gifford, 2002; Ogle et al., 2005; Zinn et al., 2005; Braz et al., 2013; Eclisa et al., 2012). For both surface soil depth intervals investigated in paired sites, 2 out of 13 sites involving native vegetation-to-pasture conversions showed higher carbon stocks than the native vegetation, and two others were virtually neutral (Fig. 3). For native vegetation-to-cropland system conversion there was also a net loss of carbon, but a third of the sites showed an increase in soil carbon stocks and the remaining two-thirds showed losses of stock (Fig. 3). In general, it seems that losses or gains of carbon are affected by the management system (Carvalho et al., 2010; Braz et al., 2013). For instance, well-managed pastures have the capability of increasing carbon soil stocks, while poorly managed pastures may lose carbon compared to the original vegetation (Guo and Gifford, 2002; Maia et al., 2009; Braz et al., 2013). In addition, the CPS systems sampled in this work were well-managed agriculture systems, including no 


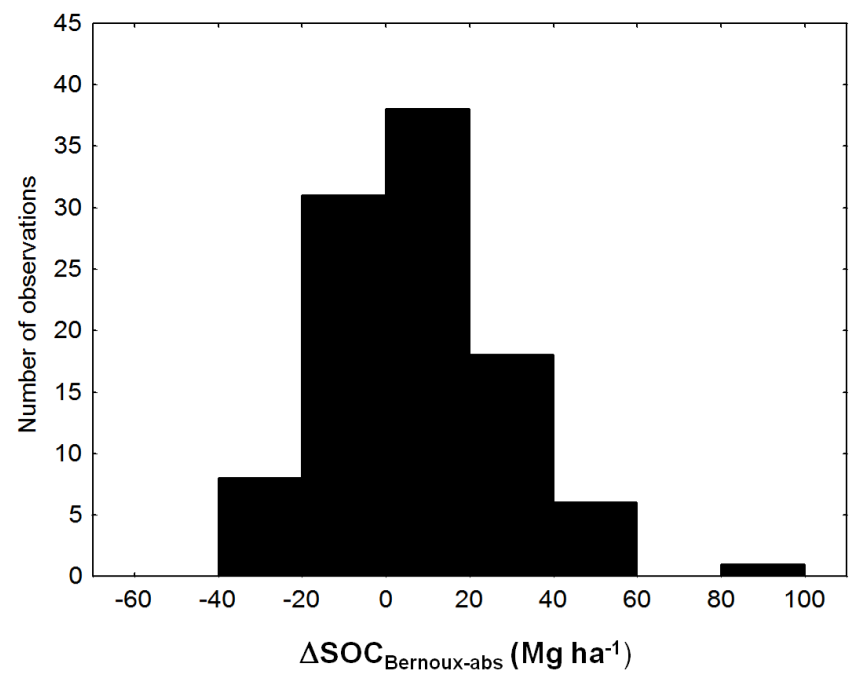

Fig. 6. Histograms of differences in carbon soil stocks between pasture soils and the carbon soil stock of native vegetation ( $\Delta \mathrm{C}_{\text {Bernoux-abs }}$ ) obtained by Bernoux et al. (2002).

till, and crop-livestock integration, which may help to accumulate carbon in the soil (Bernoux et al., 2006; Govaerts et al., 2009; Powlson et al., 2011) at least in the soil surface (Baker et al., 2007). Bayer et al. (2006) have estimated for the $0-20 \mathrm{~cm}$ depth interval a carbon gain in the soil under no till of almost $0.50 \mathrm{Mg} \mathrm{ha}^{-1} \mathrm{yr}^{-1}$ and $0.35 \mathrm{Mgha}^{-1} \mathrm{yr}^{-1}$ in the southern region of Brazil and in the Cerrado area, respectively.

Finally, it is interesting to note that in the $0-60 \mathrm{~cm}$ depth interval, although the average soil carbon stock of native vegetation was higher than the average soil carbon stocks of CPS and pasture, these differences were not significant, nor were the $\Delta \mathrm{SOC}_{\mathrm{abs}}$ and $\Delta \mathrm{SOC}_{\text {rel }}$ statistically different between land uses (Table 4). These results are consistent with other studies, like Baker et al. (2007) who in reviewing several studies conducted in the US concluded that differences in carbon soil stocks between till and no till tend to disappear at soil depths greater than $30 \mathrm{~cm}$. Eclisa et al. (2012) also found that differences in carbon soil stocks between native vegetation and pastures were only observed in more surface soil layers.

\subsection{Changes in carbon stocks with soil cultivation - regional soil pasture survey}

The regional survey of pasture soils done in this study produce contradictory results in terms of changes in carbon soil stocks as is common in the literature, where pasture soils may gain or lose carbon mainly according to their level of management (Camargo et al., 1999; Trumbore et al., 1995; Maia et al., 2009; Braz et al., 2013). Comparing pasture soils with the native vegetation carbon stocks estimated by Bernoux et al. (2006), which are very similar to the values adopted by
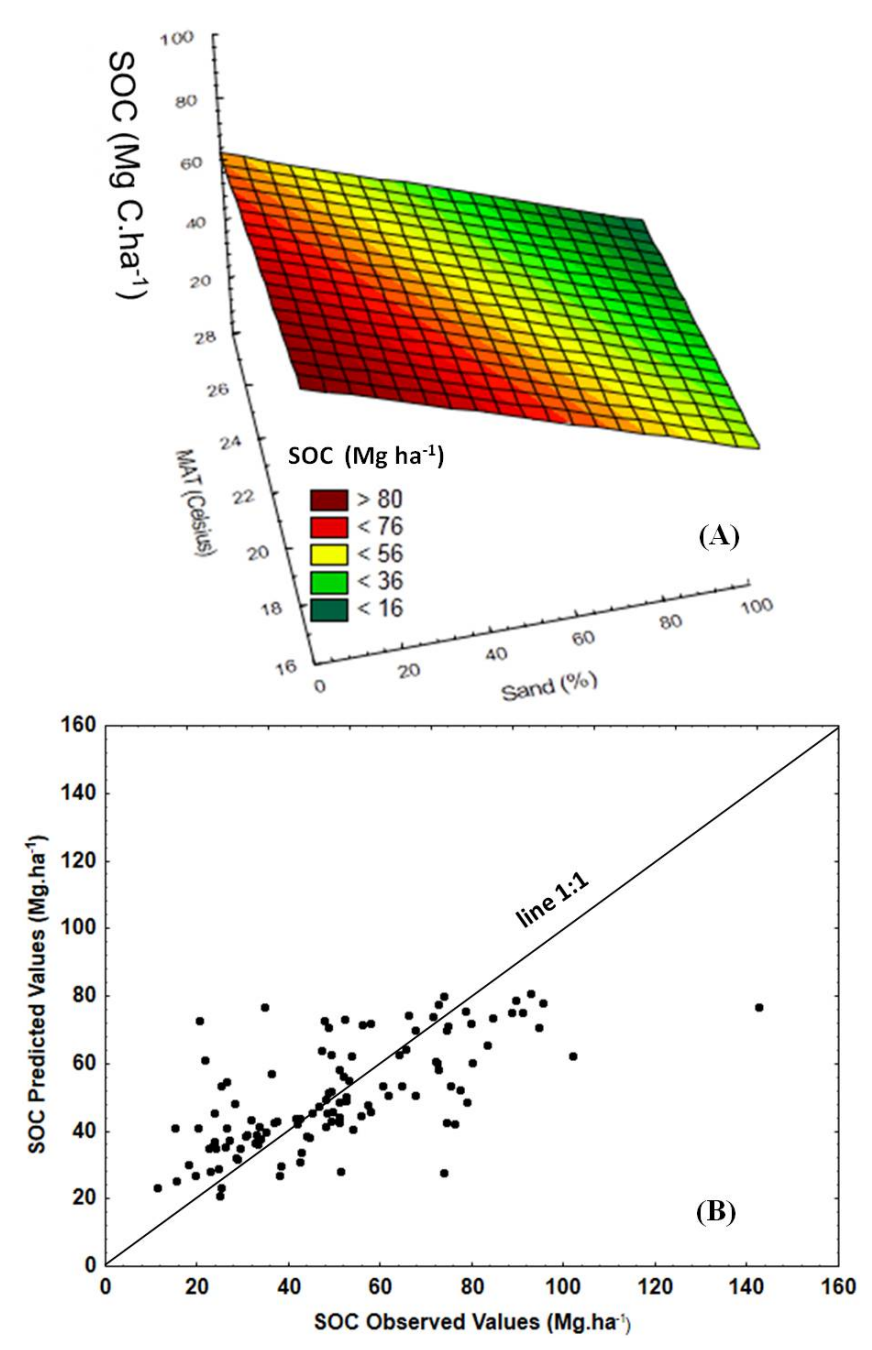

Fig. 7. (A) Tri-dimensional plot of soil carbon stocks at $0-30 \mathrm{~cm}$ in pasture soils in relation to mean annual temperature (MAT), and sand content (\%) according to Eq. (7). (B) Scatter plot of observed soil carbon stocks at $0-30 \mathrm{~cm}$ in pasture soils compared to predicted soil carbon stocks by Eq. (7).

the IPCC (Batjes et al., 2011), $40 \%$ of the sites showed a soil carbon stock loss, and $60 \%$ of the sites showed a soil carbon stock gain compared to the native vegetation (Fig. 6). Overall there was a carbon gain of approximately $7 \mathrm{Mg} \mathrm{ha}^{-1} \mathrm{yr}^{-1}$ (equivalent to $+15 \%$ ) (Table 5). The increase in soil carbon stock $(0-30 \mathrm{~cm}$ depth) with the replacement of the original vegetation by pasture was also observed in a regional survey done in South America (Eclisa et al., 2012). However, as already mentioned, the same authors also showed that there was a decrease in soil carbon stock from 30 to $100 \mathrm{~cm}$ depth to counterbalance the carbon gains observed in the topsoil; as a result, there was not a significant change in carbon stocks considered at a depth of $100 \mathrm{~cm}$.

In conclusion, our paired study sites showed a carbon soil stock loss, and our regional pasture survey showed a gain 
in the native vegetation-pasture conversion compared with native vegetation data from Bernoux et al. (2002). Several factors may explain such differences: the soil carbon stocks of native vegetation could be very different according to the climate and soil type (Batjes, 2011); the grazing conditions of pasture has a strong influence on soil carbon stocks (Braz et al., 2013); we cannot exclude the possibility that differences among areas were already there before changes in land use; and finally, we do not know if the soil organic matter in several of our sampling sites already reached a steadystate equilibrium after disturbance (Sanderman and Baldock, 2010). Perhaps more importantly, these contradictions indicate the difficulty in comparing Tier 1 (regional pasture surveys) with Tier 2 or 3 (paired study sites) type strategies established by IPCC in data poor regions of the world (Smith et al., 2012). At the same time, such contradictions are clearly indicative of the fact that, at least in Brazil, there is a need for detailed studies on changes in soil carbon stocks due to land use change coupled with a modeling effort.

\subsection{Depth variability of $\delta^{13} \mathrm{C}$ in forests and pastures of paired study sites}

It is generally accepted that an increase of up to 3-4\%o in the soil profile is caused by organic matter decomposition. Soil depth increases in $\delta^{13} \mathrm{C}$ higher than this threshold are generally interpreted as a sign of the presence of $\mathrm{C}_{4}$ carbon in the soil's organic matter (Martinelli et al., 1996; Ehleringer et al., 2000; Schwendenmann and Pendall, 2006; Yonekura et al., 2012). The presence of $\mathrm{C}_{4}$, in turn, could be due to some recent land changes that introduced $\mathrm{C}_{4}$ into one of the cropping systems, or due to a natural shift in vegetation (Martinelli et al., 1996; Ehleringer et al. 2000; Schwendenmann and Pendall, 2006; Yonekura et al., 2012). In three of our sites, the increase in $\delta^{13} \mathrm{C}$ was higher than 3-4\%o, indicating a past presence of $\mathrm{C}_{4}$ vegetation. Two of them, Passo Fundo (PF), and Arroio dos Ratos (AR), are experimental stations of EMBRAPA and The Universidade Federal do Rio Grande do Sul, respectively (Fig. 2). Therefore, it is possible that the dominant vegetation (forest) replaced old pastures, although it is not possible to completely rule out the existence of a natural paleo-grassland. The third site is in Coronel Xavier (CX), which is not an experimental station, and it is difficult to establish the origin of the $\mathrm{C}_{4}$ material (Fig. 2). If the hypothesis of introduced $\mathrm{C}_{4}$ pasture prevails, it is clear that a secondary forest was established in these sites.

\subsection{Controls of carbon soil stocks}

Saiz et al. (2012) found along a transect in West Africa that more than 0.80 of the variance of soil carbon stocks could be predicted by soil sand content and the difference between precipitation and evapotranspiration. In this study, in the regional survey of pasture soils, approximately 0.50 of the variance could be explained by the soil sand content and MAT.
The adjusted coefficient correlation found in this study was lower than that found by Saiz et al. (2012). This was somewhat expected since pasture sites of regional survey include several types of management that exert a key role in determining soil carbon stocks (Camargo et al., 1999; Trumbore et al., 1999; Maia et al., 2009; Carvalho et al., 2010).

Another interesting point already noted by Saiz et al. (2012) is that soil sand content was more important than clay as a predictor of soil carbon stocks under pasture. As reported throughout the literature, clay content generally has a direct correlation with soil carbon content (Feller and Bearer, 1997) since clay may exert a protection against organic matter decomposition. However, it seems that such protection depends more on the type of clay and contents of $\mathrm{Al}$ and $\mathrm{Fe}$ sesquioxides than the amount of clay (Bruun et al., 2010). In turn, sesquioxides impart a sand-like texture to tropical soils; this type of texture interferes with the soil water retention capacity and soil bulk density, which are key components in the soil organic matter liability and soil carbon stocks (Saiz et al., 2012).

Therefore, besides management practices, if the main goal is to implement grasslands that are able to maintain at least the same soil carbon stock compared to the native vegetation, sandy soils should be avoided.

Mean annual temperature was also important in the control of soil carbon content in the case of pasture soils. This fact is mainly due to the effect of the temperature on decomposition rates of soil organic matter (e.g. Raich et al. 2006; Wagai et al. 2008). Temperature increases were shown to enhance organic matter decomposition and soil respiration, leading to carbon losses through $\mathrm{CO}_{2}$ emissions into the atmosphere (Dorrepaal et al., 2009).

\section{Conclusion}

Our paired study sites showed an average loss of carbon soil stocks compared to either pasture or crop-livestock systems in relation to the native vegetation. On the other hand, the pasture regional survey showed an average gain of carbon soil stocks. Although we fully recognized the importance of using regional average carbon stocks in data-poor tropical regions of the world, we also should call attention to the fact that the use of such averages leads to different results in relation to plot-level paired sites, without it being feasible to clearly discern which was the most accurate comparison. 


\section{Appendix A}

\section{Bulk density (g.cm-3)}
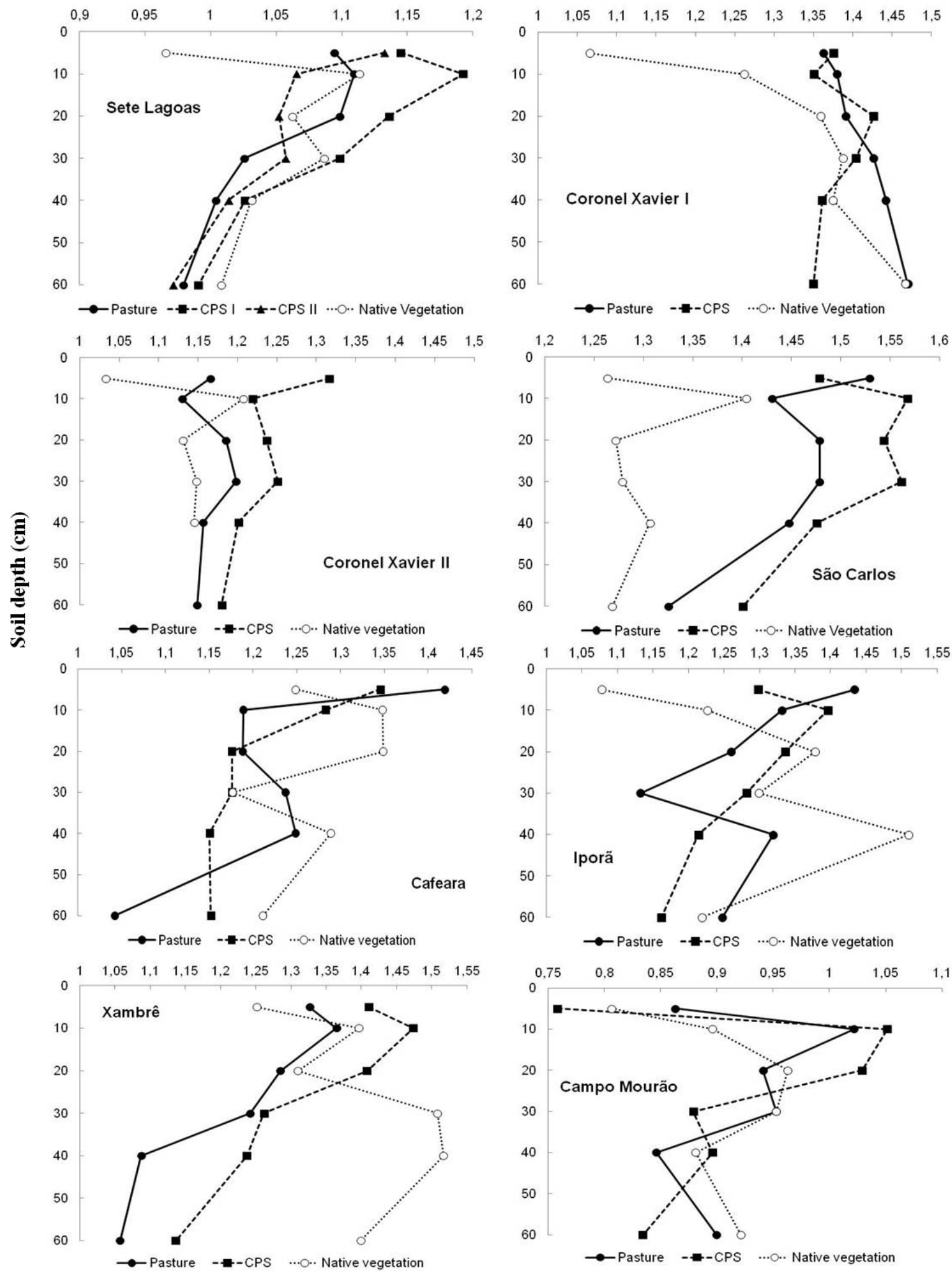

Fig. A1. Soil depth variability of soil bulk density in different land uses. 


\section{Bulk density $\left(\mathrm{g}^{\mathrm{cm}} \mathrm{cm}^{-3}\right)$}

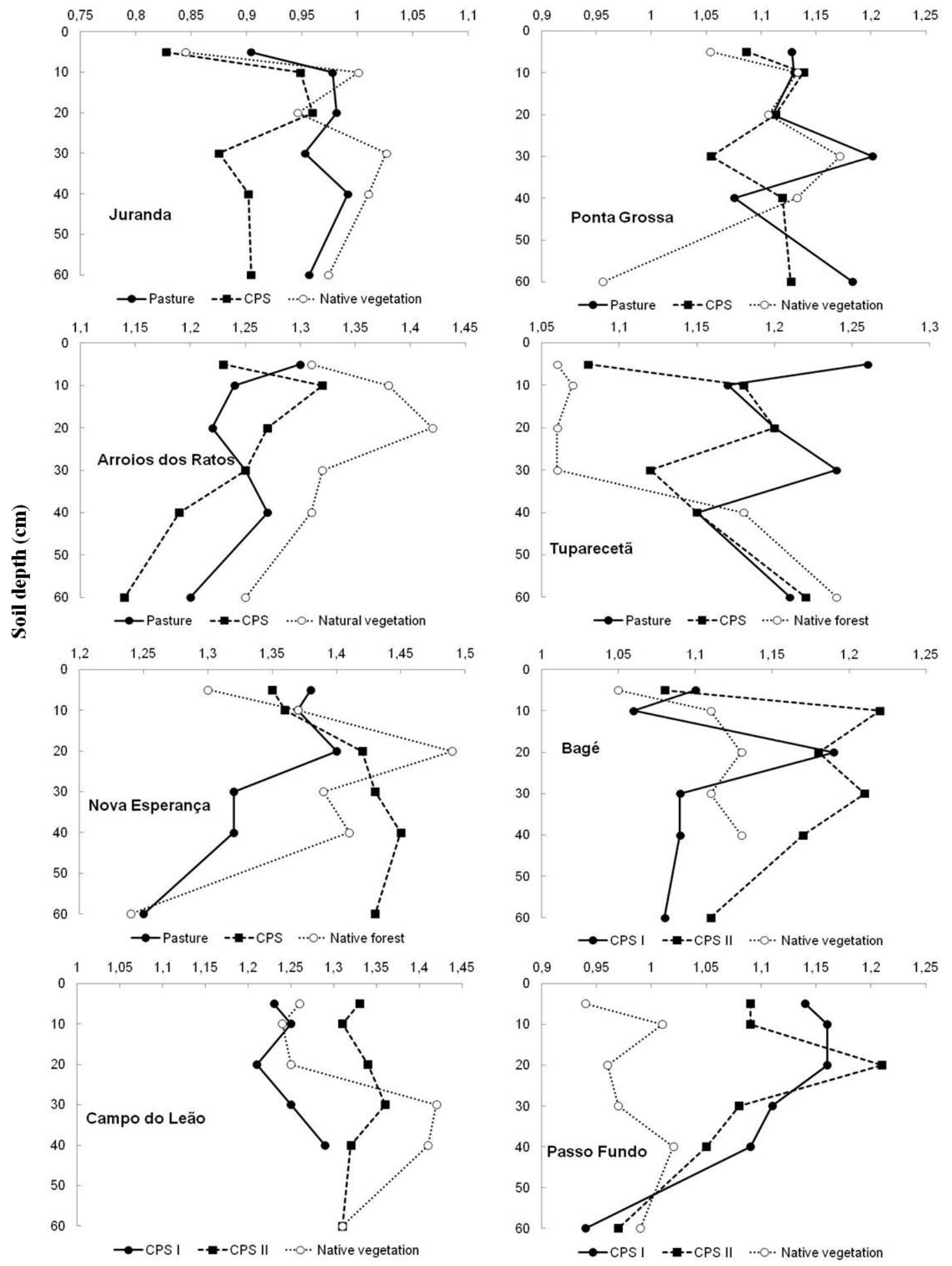

Fig. A1. Continued. 
Clay content $(\%)$

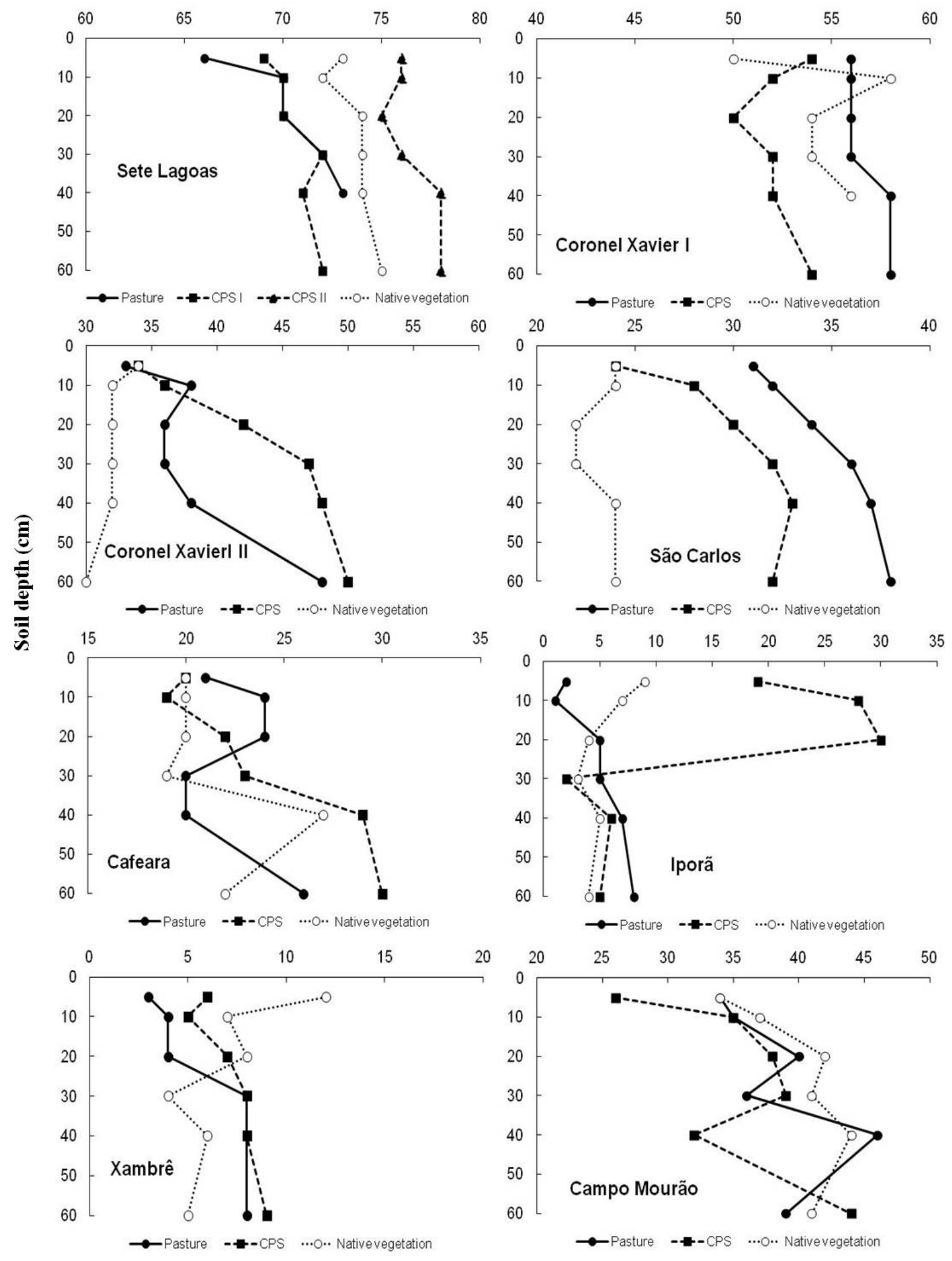

Fig. A2. Soil depth variability of soil clay content in different land uses. 


\section{Clay content (\%)}

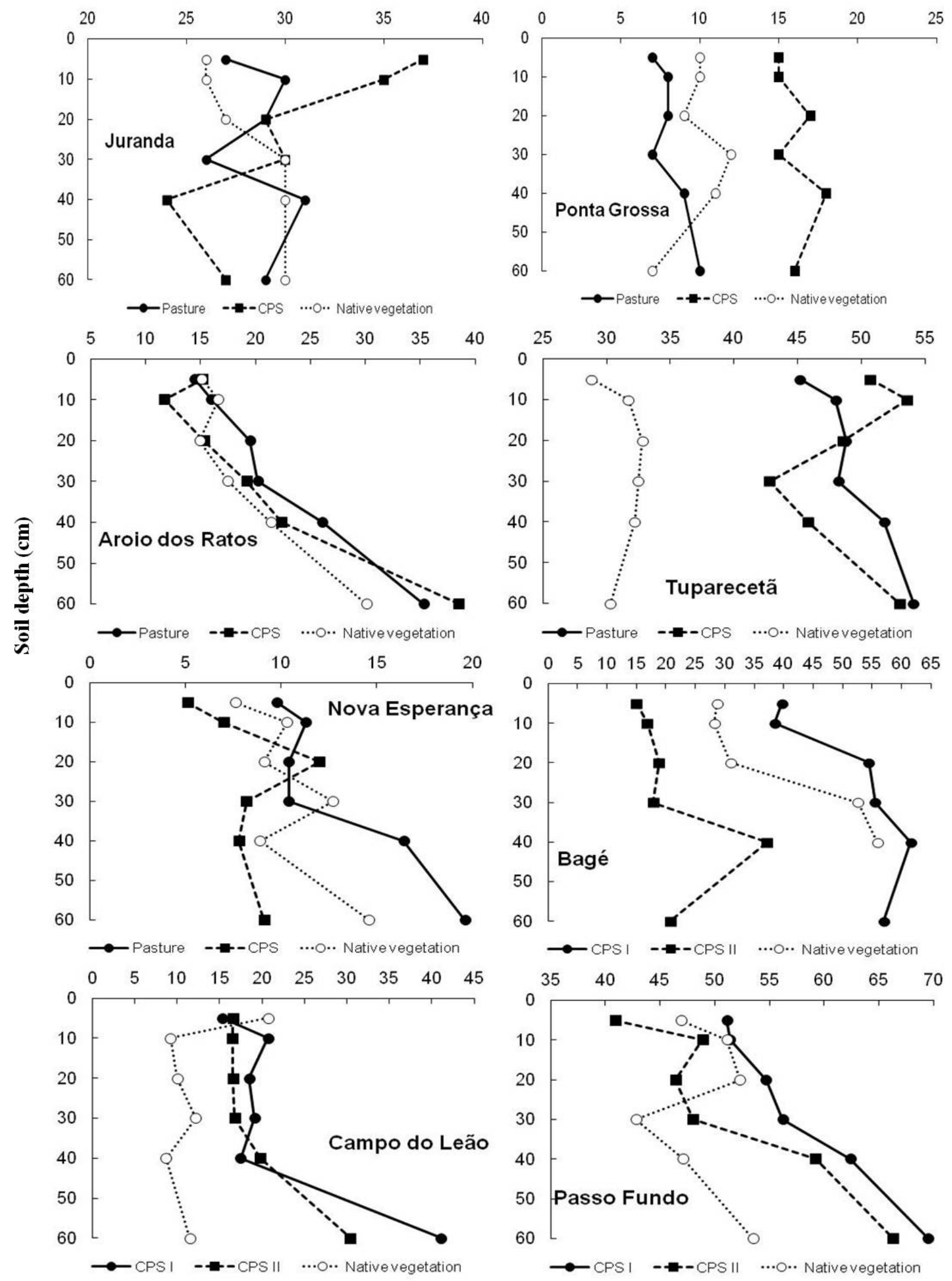

Fig. A2. Continued. 
Acknowledgements. We would like to thank the British Embassy for financial support. Jim Hesson of AcademicEnglishSolutions.com revised the English.

Edited by: P. Stoy

\section{References}

Amundson, R.: The Carbon Budget in Soils, Annu. Rev. Earth Planet. Sc., 29, 535-562, 2001.

Baker, J. M., Ochsner T. E., Ventera, R. T., and Giffis, T. J.: Tillage and soil carbon sequestration: What do we really know?, Agr. Ecosyst. Environ., 118, 1-5, 2007.

Batjes, N. H.: Soil Organic Carbon Stocks Under Native Vegetation - Revised Estimates for Use with the Simple Assessment Option of the Carbon Benefits Project System, Agr. Ecosyst. Environ., 142, 365-373, 2011.

Bayer, C., Martin-Neto, L., Mielniczuk, J., Pavinato, A., and Dieckow, J.: Carbon Sequestration in Two Brazilian Cerrado Soils Under No-till, Soil Till. Res., 86, 237-245, 2006.

Bernoux, M., Arrouays, D., Volkoff, B., Cerri, C. C., and Jolivet, C.: Bulk densities of Brazilian Amazon soils related to other soil properties, Soil Sci. Soc. Am. J., 62, 743-749. 1998.

Bernoux, M. B., Cerri, C. C., Cerri, C. E., Siqueira-Neto, M., and Metay, A. M.: Review article Cropping systems, carbon sequestration and erosion in Brazil, a review 1, Agron. Sustain. Dev., 26, 1-8, doi:10.1051/agro:2005055, 2006.

Bernoux, M. B., Carvalho, M. D. S., Volkoff, B., and Cerri, C. C.: Brazil's soil carbon stocks, Soil Sci. Soc. Am. J., 66, 888-896, 2002.

Boddey, R. M., Jantalia, C. P., Conceição, P. C., Zanata, J. A., Cimélio, B., Mielniczuk, J., Dieckow, J., Santos, H. P., Denardins, J. E., Aita, C., Giacomini, S. J., Alves, B. J. R., and Urquiaga, S.: Carbon accumulation at depth in Ferralsols under zero-till subtropical agriculture, Glob. Change Biol., 16, 784795. doi:10.1111/j.1365-2486.2009.02020.x, 2010.

Braz, S. P., Urquiaga, S., Alves, B. J. R., Jantalia, C. P., Guimarães, A. P., dos Santos, C. A., dos Santos, S. C., Pinheiro, E. F. M., and Boddey, R. M.: Soil Carbon Stocks under Productive and Degraded Brachiaria Pastures in the Brazilian Cerrado, Soil Sci. Soc. Am. J., 77, 914-928, 2013.

Bruun, T. B., Elberling, B., and Christensen, B. T.: Lability of Soil Organic Carbon in Tropical Soils with Different Clay Minerals, Soil Biol. Biochem., 42, 888-895, 2010.

Camargo, P. B., Trumbor, S., Martinelli, L. A., Davidson, E. A., Nepstad N. E., and Victoria R. L.: Soil carbon dynamics in regrowing forest of eastern Amazonia, Glob. Change Biol., 5, 693$702,1999$.

Carvalho, J. L. N., Raucci, G. S., Cerri, C. E. P., Bernoux, M., Feigl, B. J., Wruck, F. J., and C. C. Cerri.: Soil \& Tillage Research Impact of Pasture, Agriculture and Crop-livestock Systems on Soil C Stocks in Brazil, Soil Till. Res., 110, 175-186, 2010.

Chen, S., Huang, Y., Zou, J., and Shi, Y.: Mean residence time of global topsoil organic carbon depends on temperature, precipitation and soil nitrogen, Glob. Planet. Change, 100, 99-108, doi:10.1016/j.gloplacha.2012.10.006, 2013.

Davidson, E. A. and Ackerman, I. L.: Changes in soil carbon inventories following cultivation of previously untilled soils, Biogeochemistry, 20, 161-193, 1993.
Don, A., Schumacher, J., and Freibauer, A.: Impact of Tropical Land-use Change on Soil Organic Carbon Stocks - a Meta-analysis, Glob. Change Biol., 17, 1658-1670, doi:10.1111/j.1365-2486.2010.02336.x, 2011.

Dorrepaal, E., Toet, S., Van Logtestijn, R. S. P., Swart, E., Van De Weg, M. J., Callaghan, T. V., and Aerts, R.: Carbon Respiration from Subsurface Peat Accelerated by Climate Warming in the Subarctic, Nature, 460, 616-619, 2009.

Eclesia, R. P., Jobbagy, E. G., Jackson, R. B., Biganzoli, F., and Piñeiro, G.: Shifts in soil organic carbon for plantation and pasture establishment in native forests and grasslands of South America, Glob. Change Biol., 18, 3237-3251, doi:10.1111/j.1365-2486.2012.02761.x, 2012.

Ehleringer, J. R., Buchmann, N., and Flanagan, L. B.: Carbon isotope ratios in belowground carbon cycle processes, Ecol. Appl., 10, 412-422, 2000.

Ellert, B. H., Janzen, H. H., Van den Bygaart, A. J. and Bremer, E.: Measuring Change in Soil Organic Carbon Storage, in: Soil sampling and methods of analysis, edited by: Carter, M. R. and Gregorich, E. G., CRC Press, Boca Raton, USA, Chapter 3, 2008.

EMBRAPA - Empresa Brasileira de Pesquisa Agropecuária.: Manual de métodos de análise do solo. Rio de Janeiro: EMBRAPA, CNCS, 212 pp., 1997.

Feller, C. and Beare, M. H.: Physical control of soil organic matter dynamics in the tropics, Geoderma, 79, 69-116, 1997.

Fisher, M. J., Rao, I. M., Ayarza, M. A., Lascano, C. E., Sanz, J. I., Thomas, R. J., and Vera, R. R.: Carbon storage by introduced deep-rooted grasses in the South American savannas, Nature, 371, 236-238, 1994.

Govaerts, B., Verhulst, N., Castellanos-Navarrete, A., Sayre, K. D., Dixon, J., and Dendooven, L.: Conservation Agriculture and Soil Carbon Sequestration: Between Myth and Farmer Reality, CRC Cr. Rev. Plant Sci., 28, 97-122, 2009.

Guo, L. B. and Gifford, R. M.: Soil Carbon Stocks and Land Use Change: a Meta Analysis, Glob. Change Biol., 8, 345-360, doi:10.1046/j.1354-1013.2002.00486.x, 2002.

IPCC, Intergovernmental Panel of Climate Change: Guidelines for National Greenhouse Gas Inventories, Prepared by the National Greenhouse Gas Inventories Programme, edited by: Eggleston $\mathrm{H}$. S., Buendia, L., Miwa, K., Ngara, T., and Tanabe, K., Published: IGES, Japan, 2006.

Jobbágy, E. G. and Jackson, R. B.: The Vertical Distribution of Soil Organic Carbon and Its Relation to Climate and Vegetation, Ecol. Appl., 10, 423-436, doi:10.1890/10510761(2000)010[0423:TVDOSO]2.0.CO;2, 2000.

Lal, R.: Enhancing Eco-efficiency in Agro-ecosystems through Soil Carbon Sequestration, Crop Sci., 50, 120-131, doi:10.2135/cropsci2010.01.0012, 2010.

Leite, C. C., Costa, M. H., Soares-Filho, B. S., and De Barros Viana Hissa, L.: Historical land use change and associated carbon emissions in Brazil from 1940 to 1995, Global Biogeochem. Cy., 26, 1-13, doi:10.1029/2011GB004133, 2012.

Lisboa, C. C., Conant, R. T., Haddix, M. L., Cerri, C. E. P., and Cerri, C. C.: Soil Carbon Turnover Measurement by Physical Fractionation at a Forest-to-Pasture Chronosequence in the Brazilian Amazon, Ecosystems, 12, 1212-1221, doi:10.1007/s10021-009-9288-7, 2009. 
Maia, S., Ogle, S., and Cerri, C.: Effect of grassland management on soil carbon sequestration in Rondônia and Mato Grosso states, Brazil, Geoderma, 149, 84-91, 2009.

Maia, S. M. F., Ogle, S. M., Cerri, C. E. P., and Cerri, C. C.: Soil organic carbon stock change due to land use activity along the agricultural frontier of the southwestern Amazon, Brazil between 1970 and 2002, Glob. Change Biol., 16, 2775-2788, 2010.

Marchão, R. L., Becquer, T., Brunet, D., Balbino, L. C., Vilela, L., and Brossard, M.: Carbon and nitrogen stocks in a Brazilian clayey Oxisol: 13-year effects of integrated crop-livestock management systems, Soil and Tillage Research, 103, 442-450, 2009.

Martinelli, L. A., Pessenda, L. C. R., Espinoza, E., Camargo, P. B., Telles, E. C., Cerri, C. C., Victoria, R. L., Aravena, R., Richey, J., and Trumbore, S.: Carbon-13 variation with depth in soils of Brazil and climate change during the Quaternary, Oecologia, 106, 376-381, 1996.

Martinelli, L. A., Naylor, R., Vitousek, P. M., and Moutinho, P.: Agriculture in Brazil: impacts, costs, and opportunities for a sustainable future, Current Opinion in Environmental Sustainability, 2, 431-438, doi:10.1016/j.cosust.2010.09.008, 2010.

MCT.: Inventário Brasileiro de Emissões Antrópicas por Fontes e Remoções por Sumidouros de Gases de Efeito Estufa não Controlados pelo Protocolo de Montreal - Parte 2, 2010.

Ogle, S. M., Breidt F. J., and Paustian, K.: Agricultural management impacts on soil organic carbon storage under moist and dry climatic conditions of temperate and tropical regions, Biogeochemistry, 72, 87-121, doi:10.1007/s10533-004-0360-2, 2005.

Post, W. M., Emanuel, W. R., Zinke, P. J., and Stangenberger, A. G.: Soil carbon pools and world life zones, Nature, 298, 156$159,1982$.

Powlson, D. S., Gregory, P. J., Whalley, W. R., Quinton, J. N., Hopkins, D. W., Whitmore, A. P., Hirsch, P. R., and Goulding, K. W. T.: Soil Management in Relation to Sustainable Agriculture and Ecosystem Services, Food Policy, 36, S72-S87, doi:10.1016/j.foodpol.2010.11.025, 2011.

Raich, J. W. and Potter, C. S.: Global patterns of carbondioxide emissions from soils, Global Biogeochem. Cy., 9, 23-36, 1995.

Raich, J. W., Russell, A. E., Kitayama, K., Parton, W. J., and Vitousek, P. M.: Temperature influences carbon accumulation in moist tropical forests, Ecology, 87, 76-87, 2006.

Sá, J. C. M., Cerri, C. C., Dick, W. A., Lal, R., Venske Filho, S. P., Piccolo, M. P., and Feigl, B. E.: Organic Matter Dynamics and Carbon Sequestration Rates for a Tillage Chronosequence in a Brazilian Oxisol, Soil Sci. Soc. Am. J., 65, 1486-1499, 2001.
Saiz, G., Bird, M. I., Domingues, T., Schrodt, F., Schwarz, M., Feldpausch, T. R., and Veenendaal, E.: Variation in Soil Carbon Stocks and Their Determinants Across a Precipitation Gradient in West Africa, Glob. Change Biol., 18, 1670-1683, doi:10.1111/j.1365-2486.2012.02657.x, 2012.

Sanderman, J. and Baldock, J. A.: Accounting for soil carbon sequestration in national inventories: a soil scientist's perspective, Environ. Res. Lett., 5, 1-6, 2010.

Schwendenmann, L. and Pendall, E.: Effects of forest conversion into grassland on soil aggregate structure and carbon storage in Central Panama: evidence from soil carbon fractionation and stable isotopes, Plant Soil, 288, 217-232, 2006.

Smith, P., Davies, C. A., Ogle, S., Zanchi, G., Bellarby, J., Bird, N., Boddey, R. M., McNamara, N. P., Powlson, D., Cowie, A., Noordwijk, M., Davis, S. C., Richter, D. D. B., Kryzanowski, L., Wijk, M. T., Stuart, J., Kirton, A., Eggar, D., Newton-Cross, G., Adhya, T. K., and Braimoh, A. K.: Towards an integrated global framework to assess the impacts of land use and management change on soil carbon: current capability and future vision, Glob. Change Biol., 18, 2089-2101, 2012.

Trumbore, S. E., Davidson, E. A., Camargo, P. B., Nepstad, D. C., and Martinelli, L. A.: Belowground cycling of carbon in forests and pastures of Eastern Amazonia, Global Biogeochem. Cy., 9, 515-528, 1995.

Wagai, R., Mayer, L. M., Kitayama, K., and Knicker, H.: Climate and Parent Material Controls on Organic Matter Storage in Surface Soils?: A Three-pool, Density-separation Approach, Wagai, 147, 23-33, 2008.

Wendt, J. W. and Hauser, An equivalent soil mass procedure for monitoring soil organic carbon in multiple soil layers, Eur. J. Soil Sci., 64, 58 -65, 2013.

Yonekura, Y., Ohta, S., Kiyono, Y., Aksa, D., Morisada, K., Tanaka, N., and Tayasu, I.: Dynamics of soil carbon following destruction of tropical rainforest and the subsequent establishment of Imperata grassland in Indonesian Borneo using stable carbon isotopes, Glob. Change Biol., 18, 2606-2616, doi:10.1111/j.13652486.2012.02722.x, 2012.

Zinn, Y. L., Lal, R., and Resck, D. V. S.: Changes in Soil Organic Carbon Stocks Under Agriculture in Brazil, Soil Till. Res., 84, 28-40, http://linkinghub.elsevier.com/retrieve/pii/ S0167198704001862, 2005. 